\title{
Trace metal contamination in soils from mountain regions across China: spatial distribution, sources, and potential drivers
}

\author{
Haijian Bing ${ }^{1,{ }^{*}}$, Shaojun Qiu ${ }^{1,2}$, Xin Tian ${ }^{1,2}$, Jun $\mathrm{Li}^{3}$, He Zhu ${ }^{1}$, Yanhong $\mathrm{Wu}^{1,{ }^{*}}$, Gan Zhang ${ }^{3}$ \\ 1 Key Laboratory of Mountain Surface Processes and Ecological Regulation, Institute of Mountain Hazards and Environment, \\ Chinese Academy of Sciences, Chengdu 610041, China \\ 2 University of Chinese Academy of Sciences, Beijing 100049, China \\ 3 State Key Laboratory of Organic Geochemistry, Guangzhou Institute of Geochemistry, Chinese Academy of Sciences, Guangzhou 510640, \\ China
}

\section{H I G H L I G H T S}

- Trace metal contamination in soils of 29 China's mountains was investigated.

- Cd was the priority control metal with moderate to heavy contamination.

- $\mathrm{Cd}$ and $\mathrm{Pb}$ contamination were higher in northwest, south and southwest China.

- Atmospheric deposition was the main sources of $\mathrm{Cd}$ and $\mathrm{Pb}$ in soils.

- Climate, vegetation and soil properties regulated spatial distribution of trace metals.

\section{ARTICLE INFO}

Article history:

Received December 18, 2020

Revised January 25, 2021

Accepted February 1, 2021

Keywords:

Trace metals

Soil contamination

Source identification

Atmospheric deposition

Driving factors

Mountain regions

\section{GRAPHICAL ABSTRACT}

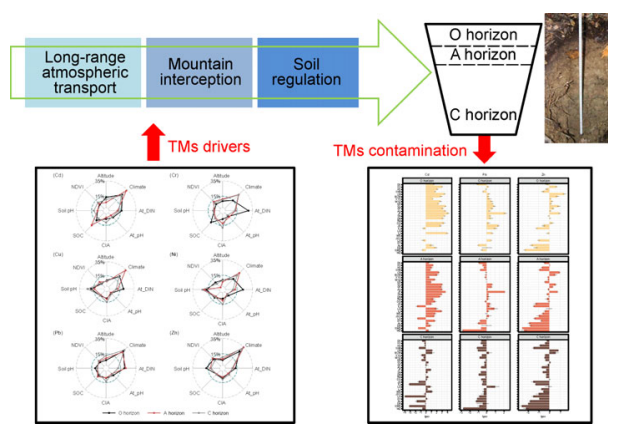

Trace metal contamination in soils is a threat with an uncertain limit to maintain planet safety, and the issue of trace metal contamination in mountain soils is still of low concerned. In this study, we assessed the contamination of six trace metals ( $\mathrm{Cd}, \mathrm{Cr}, \mathrm{Cu}, \mathrm{Ni}, \mathrm{Pb}$, and $\mathrm{Zn}$ ) in mountain soils across China and deciphered the potential drivers of their spatial distribution. The results showed that concentrations of $\mathrm{Cd}$ and $\mathrm{Pb}$ decreased significantly with soil depth, and their concentrations were markedly higher in northwest, south, and southwest China than elsewhere. Among the metals, Cd was the priority for control with moderate to heavy contamination, followed by $\mathrm{Pb}$, whereas the other metals did not show evident contamination. The altitudinal pattern and isotopic tracing revealed that the significant enrichment and marked contamination of $\mathrm{Cd}$ and $\mathrm{Pb}$ in surface soils were primarily attributed to deposition through long-range transboundary atmospheric transport and condensation. Ore mining, nonferrous smelting, and coal and fuel combustion were identified as primary anthropogenic sources of the $\mathrm{Cd}$ and $\mathrm{Pb}$. Soil organic matter content, $\mathrm{pH}$, and soil forming processes directly determined the accumulation of trace metals in the soils, and orographic effects, including local climate, vegetation composition, and canopy filtering, regulated the spatial distribution of the metals. This study highlights the significance of soil $\mathrm{Cd}$ contamination in mountains, which are considered of low concern, and suggests that long-term monitoring of trace metal contamination is necessary to improve biogeochemical models that evaluate the responses of the mountain critical zone to future human- and climate-induced environmental changes.

\footnotetext{
* Corresponding authors

E-mail address: hjbing@imde.ac.cn (H. Bing); yhwu@imde.ac.cn (Y. Wu)
} 


\section{Introduction}

Heavy metal contamination poses a risk to the Earth system, and there is uncertainty around the level of heavy metal contamination that falls safely within planetary boundaries (Rockstrom et al., 2009; Steffen et al., 2015). Especially since the Anthropocene, the emission of trace metals into the environment has been increasing because of human activities, such as mining and smelting, fossil fuel combustion, and industrial and agricultural production (Bing et al., 2016a; Tóth et al., 2016; Natalia et al., 2019). Excess or unacceptable accumulation of trace metals in soils can endanger soil functioning and threaten human health through accumulation in the food chain (Oliver, 1997; Abraham, 2002; Satarug et al., 2010; Duan et al., 2018). Because of high toxicity, environmental persistence, and biomagnification, trace metals, such as cadmium ( $\mathrm{Cd}$ ), lead $(\mathrm{Pb})$, and chromium $(\mathrm{Cr})$, have been listed by Green Cross Switzerland and Pure Earth (https:// www.worstpolluted.org/) as the most harmful toxic threats to human health. Therefore, it is necessary to continuously focus on soil safety from trace metal contamination.

With increasing industrialization and urbanization, the contamination of soils with trace metals is becoming an increasingly concerning environmental issue in China (Chen et al., 2015; Zhao et al., 2015; Yang et al., 2018; Hou et al., 2019). According to the National Soil Survey Report (MEP, 2014), $16.1 \%$ of soil samples exceed the national environmental quality standard set by the Ministry of Environmental Protection for the acceptable amount of trace metals. Of the trace metals, $\mathrm{Cd}$ is listed as one of the priority trace metal pollutants in China's soils, and it ranks first in the percentage of samples $(7 \%)$ exceeding the standard. Over the past 40 years, the concentration of soil $\mathrm{Cd}$ in the southern coastal area has increased by $>50 \%$, and the percentage increases in north, northeast, and west China has reached 10\%-40\% (Liu et al., 2016; Yang et al., 2018; Huang et al., 2019). Because of the direct effects of trace metals on human health, most studies have investigated the contamination of trace metals in farmland soils (Niu et al., 2013; Liu et al., 2016; Huang et al., 2019), major cities (Wei and Yang, 2010; Sun et al., 2019), and mining areas (Li et al., 2014; Xiao et al., 2017). However, limited attention has been paid to the soils of remote mountain regions, which limits our understanding of the geographic patterns of trace metal contamination in soils at the national scale. More importantly, China's mountains provide plentiful economic and socioecological resources, services, and functions for humans, including playing a vital role in regulating climate changes (Wu and Bing, 2012). If mountain soils become contaminated by trace metals, their services and functions will be reduced, partially because of the shallow soil layers at high altitudes and their susceptibility to soil erosion (Le Roux et al., 2020).

The mountain critical zone features capricious climate, complex topographic conditions, and a relatively primitive and fragile ecological environment, which is sensitive to rapid climate and environmental changes (Le Roux et al., 2016).
Despite the long distance between mountains and industrial and/or urban centers, mountains are sinks of long-range transported pollutants, including trace metals. Many researchers have observed trace metal contamination in mountain soils because of long-range transboundary atmospheric transport and the effect of cold condensation leading to the deposition of trace metals (Zechmeister, 1995; Steinnes and Friedland, 2006; Hovmand et al., 2008; Bing et al., 2016b). Thus, humans and animals could face a risk of exposure to trace metals. With rapid climate and environmental changes, especially increased extreme climatic events, the trace metals accumulated in soils can be remobilized by intense grazing activities, soil erosion, or acidification, causing secondary pollution input (Bacardit and Camarero, 2010; Hansson et al., 2017; Le Roux et al., 2020). Therefore, there is urgency to assess the contamination characteristics of soil trace metals and uncover their potential drivers in mountain regions.

The distribution and fate of trace metals in mountain soils is controlled by many complex drivers. First, parent materials are closely related to the levels of trace metals in soils, which has been well recognized in farmland and mining soils (Chen et al., 2015; Huang et al., 2019; Hou et al., 2020). There is substantial spatial heterogeneity in the background of trace metals across China. For instance, the geological background of $\mathrm{Cd}, \mathrm{Pb}$, and zinc $(\mathrm{Zn})$ is relatively higher in southwest and south China than other regions. The characteristics of parent rocks, weathering duration, and soil development also affect patterns in the contamination of trace metals in soils. Secondly, many human activities, including ore mining, nonferrous metal smelting, energy consumption, and industrial production, have resulted in a large amount of trace metals being emitted into the environment. Therefore, the spatial heterogeneity and intensity of human activities could also alter the distribution of trace metals in remote mountains. In China, fuel consumption is relatively higher in east China than elsewhere, coal consumption is concentrated in central and north China, and polymetallic ores are primarily distributed in south, southwest, and northwest China (Liang and Zhang, 2009; Chen et al., 2013; Tian et al., 2014; Li et al., 2017). Moss biomonitoring has shown that some trace metals in China's mountains originated from anthropogenic sources, including regional anthropogenic emissions (Bing et al., 2019). Thus, we expected that the contamination of soil with trace metals in China's mountains was closely associated with regional anthropogenic emissions through long-range atmospheric transport. Additionally, within the mountain system, the fate of trace metals in soils can be regulated by microtopography, climate, vegetation distribution, and soil properties, such as organic matter and $\mathrm{pH}$ along the altitude (Andersen et al., 2004; Luo et al., 2019). For example, except plant uptake and litter return, Gandois et al. (2010) found that canopy interception could increase atmospheric metal inputs through stem flow. Additionally, Bing et al. (2018) revealed that terrain, local climate, and vegetation composition were combined to intercept the transport of atmospheric metals in the eastern Tibetan Plateau. Rieder et al. (2014) modeled the 
long-term behavior of trace metals in forest soils and found that soils rich in organic carbon or with high $\mathrm{pH}$ increased the concentrations of $\mathrm{Cd}$ and $\mathrm{Pb}$. Considering the difficulty of ecological restoration in remote uplands, it is necessary to discern the dominant or potential drivers of trace metal accumulation in soils.

In this study, 29 mountains (or mountain regions) across China were selected to collect soil samples at different altitudes and in different soil horizons, and six priority trace metals, $\mathrm{Cd}$, $\mathrm{Cr}$, copper ( $\mathrm{Cu}$ ), nickel $(\mathrm{Ni}), \mathrm{Pb}$, and $\mathrm{Zn}$, were analyzed. The primary objectives of the study were to (1) delineate the spatial distribution patterns of trace metals in China's mountain soils; (2) assess the contamination and enrichment states of the metals along the soil profile; and (3) decipher the potential drivers regulating the distribution of trace metals in mountain soils at the national scale. The results of the study will fill knowledge gaps of the geographic and geochemical characteristics of soil trace metal contamination of various land-uses at a large spatial scale.

\section{Materials and methods}

\subsection{Study area}

The study area included 29 mountains across China, most of which are located in national and provincial nature reserves. The spatial range of the study area was $18.89-53.45^{\circ} \mathrm{N}$, $100.99-129.65^{\circ} \mathrm{E}$, and the altitude varied from 240 to $4225 \mathrm{~m}$ above sea level. The study area included cold temperate, temperate, warm temperate, subtropical, and tropical climatic zones. The mean annual temperature (MAT) in the study area ranged between $-5^{\circ} \mathrm{C}$ and $21^{\circ} \mathrm{C}$, and the mean annual precipitation (MAP) varied between 223 and $1947 \mathrm{~mm}$. The specific climate, altitude, and vegetation information for each mountain is presented in Table S1.

\subsection{Sample collection}

At each mountain, the sampling sites were chosen based on the altitudinal gradient and dominant vegetation types. At each site, three $10 \mathrm{~m} \times 10 \mathrm{~m}$ blocks were randomly selected to dig the soil profile to parent materials, and then soil samples that were representative of soil development were collected, including the $\mathrm{O}$ horizon (organic soils), A horizon (mineral soils), and $\mathrm{C}$ horizon (parent materials). Due to differences in climate and vegetation, $\mathrm{O}$ horizon samples were not collected at some sites (Table S2). In total, 1385 soil samples, including 391 O horizons, 514 A horizons, and $480 \mathrm{C}$ horizons were collected. The soil samples were kept in polyethylene bags and transported to the laboratory. Then, the samples were airdried and ground using an agate mortar to pass through a 100-mesh Nylon screen for chemical analysis.

\subsection{Chemical analysis}

Soil $\mathrm{pH}$ was measured using a $\mathrm{pH}$ meter after deionized water was mixed with the soil samples at a ratio of $2.5: 1$. The content of soil organic carbon (SOC) was detected using a CE400 elemental analyzer after removal of carbonates using $5 \% \mathrm{HCl}$. For element analysis, the soil samples were digested with the sequential addition of concentrated $\mathrm{HNO}_{3}, \mathrm{HF}, \mathrm{HClO}_{4}$, and $\mathrm{HCl}$ (Bing et al., 2014). The concentrations of trace metals in the digestion solution were measured using inductively coupled plasma mass spectrometry (ICP-MS), and the concentrations of titanium ( $\mathrm{Ti}$ ) and other major elements were measured using inductively coupled plasma mass atomic emission spectrometry (ICP-AES). SPEX ${ }^{\mathrm{TM}}$ was used as the standard solution. Quality control was performed by analyzing repeats, blanks, and reference materials (GBW07405, China). The precision and accuracy for the ICP-MS and ICP-AES analysis were routinely below 5\% (relative standard deviation (RSD)), and the recovery rate of the standard material varied between $95 \%$ and $105 \%$.

The $\mathrm{Pb}$ isotope ratios $\left({ }^{206} \mathrm{~Pb} /{ }^{207} \mathrm{~Pb}\right.$ and $\left.{ }^{208} \mathrm{~Pb} /{ }^{206} \mathrm{~Pb}\right)$ in the soils were measured using ICP-MS (Agilent 7700x). A standard reference material from the United States National Institute of Standards and Technology-SRM981 $\left({ }^{208} \mathrm{~Pb} /{ }^{206} \mathrm{~Pb}\right.$ $\left.=2.1681 \pm 0.0008,{ }^{207} \mathrm{~Pb} /{ }^{206} \mathrm{~Pb}=0.9146 \pm 0.00033\right)$ was selected for instrument calibration and quality control. The replicate analysis of the ${ }^{208} \mathrm{~Pb} /{ }^{206} \mathrm{~Pb}$ and ${ }^{207} \mathrm{~Pb} /{ }^{206} \mathrm{~Pb}$ ratios in the SRM981 standard showed that the precision (RSD) was $<0.07 \%$ and $<0.12 \%$, respectively.

\subsection{Calculations}

The geoaccumulation index $\left(I_{\text {geo }}\right)$ (Muller, 1969) and the enrichment factor (EFs) (Taylor and McLennan, 1995) were respectively used to reflect the contamination state and the mass balance of trace metals in the soil profiles, despite the limited role of the EFs in differentiating anthropogenic sources of soil metals. Both methods are explained in more detail in the Supplementary Materials.

\subsection{Statistical analysis}

Spearman correlation was used to evaluate the correlation between trace metals in soils, and regression analysis was utilized to examine the trends in trace metals with altitude, longitude, and latitude and to assess the relationships between trace metals in soils and those in moss and wet deposition. Boosted regression tree (BRT) analysis can be used to analyze different types of variables or predictors and fit complex nonlinear relationships (Elith et al., 2008). In this study, we used it to identify the relative contributions of all considered predictors, including climate (MAT and MAP), altitude, plant productivity (normalized difference vegetation index (NDVI)), soil properties ( $\mathrm{pH}$ and SOC), and the chemical index of alteration (CIA) to the distribution of trace metals in soils. All of these predictors can be found in Tables S1 and S2 in the Supplementary Materials. The data were in-transformed before conducting the BRT analysis. All statistical analysis in this study was performed using R 4.0.3 software. 


\section{Results}

3.1 The concentrations and spatial distribution of trace metals in the mountain soils

The concentrations of trace metals in the soil samples from China's mountains and those of other land-uses are shown in Table 1. $\mathrm{Cd}, \mathrm{Pb}$, and $\mathrm{Zn}$ concentrations decreased significantly with soil depth. However, $\mathrm{Cr}$ and $\mathrm{Ni}$ concentrations showed an opposite trend, and $\mathrm{Cu}$ concentrations did not vary among soil horizons. Compared with other land-uses, although the concentrations of soil trace metals in the mountains were markedly lower than those in mining and smelting areas, the concentrations were comparable to or even higher ( $\mathrm{Cd}$ in the $\mathrm{O}$ horizon) than those in urban and agricultural soils. Meanwhile, we calculated the proportion of soil samples with metal concentrations exceeding China's soil environmental quality standards (GB 15618-2018; Table 1). It was evident that $85.2 \%, 64.8 \%$, and $9.4 \%$ of samples in the $O$, $\mathrm{A}$, and $\mathrm{C}$ horizons, respectively, had $\mathrm{Cd}$ concentrations exceeding the quality standard. Moreover, in the $O$ and $A$ horizons, $\mathrm{Pb}$ and $\mathrm{Zn}$ displayed relatively higher proportions of samples exceeding acceptable standards of contamination than $\mathrm{Cr}, \mathrm{Cu}$, and $\mathrm{Ni}$.

There was a marked spatial difference in the distribution of trace metals in each soil horizon (Fig. S1), and the regression analysis further revealed variations in the metal concentrations with latitude, longitude, and altitude (Fig. 1). The results showed that the concentrations of all metals were relatively higher at the latitude of $\sim 35^{\circ} \mathrm{N}$ across soil horizons, except for $\mathrm{Pb}$ in the $\mathrm{C}$ horizon, and the concentrations generally displayed a decreasing trend from west to east, except for

Table 1 The concentrations (mean \pm standard error, $\mathrm{mg} \mathrm{kg}^{-1}$ ) of trace metals in soil profiles of China's mountains. The concentrations of trace metals in other land-uses at the national scale are also complied for comparison. The proportions of the samples with the metal concentrations exceeding the environmental quality standard were also shown.

\begin{tabular}{|c|c|c|c|c|c|c|c|}
\hline & $\mathrm{Cd}$ & $\mathrm{Cr}$ & $\mathrm{Cu}$ & $\mathrm{Ni}$ & $\mathrm{Pb}$ & $\mathrm{Zn}$ & References \\
\hline \multicolumn{8}{|l|}{$(n=391)$} \\
\hline \multicolumn{8}{|l|}{$(n=514)$} \\
\hline \multicolumn{8}{|l|}{$(n=480)$} \\
\hline \multicolumn{8}{|c|}{ China's soils (mean values) } \\
\hline Mine soils & 11.0 & 84.3 & 212 & 107 & 641 & 1163 & Li et al. (2014) \\
\hline $\begin{array}{l}\text { Soils in mining } \\
\text { and smelting } \\
\text { areas }\end{array}$ & 6.85 & 102 & 180 & 132 & 682 & 1171 & Teng et al. (2014) \\
\hline Urban soils & 0.25 & 67.9 & 32.8 & 27.2 & 36.3 & 99.2 & $\begin{array}{l}\text { Zhang et al. } \\
(2018)\end{array}$ \\
\hline Urban soils & 0.38 & 71.0 & 52.6 & 45.7 & 40.1 & 98.6 & Teng et al. (2014) \\
\hline Urban soils & 0.39 & 68.5 & 40.4 & 24.9 & 55.2 & 109 & Luo et al. (2012) \\
\hline Agricultural soils & 0.20 & 55.1 & 29.2 & 22.5 & 36.1 & 79.3 & Teng et al. (2014) \\
\hline Agricultural soils & 0.24 & 62.4 & 28.4 & 28.4 & 32.0 & 83.4 & $\begin{array}{l}\text { Huang et al. } \\
\text { (2019) }\end{array}$ \\
\hline Chinese soils & 0.23 & 68.5 & 27.1 & 29.6 & 31.2 & 79.0 & Chen et al. (2015) \\
\hline \multicolumn{8}{|c|}{ Soil quality standard* } \\
\hline Soil $\mathrm{pH} \leqslant 6.5$ & 0.3 & 150 & 50 & 70 & 90 & 200 & \\
\hline \multicolumn{8}{|c|}{ Proportions of the samples with the concentrations exceeding the standard } \\
\hline O horizon & $85.2 \%$ & $0.8 \%$ & $0.5 \%$ & $0.0 \%$ & $9.0 \%$ & $8.7 \%$ & This study \\
\hline A horizon & $64.8 \%$ & $3.1 \%$ & $1.4 \%$ & $0.0 \%$ & $5.3 \%$ & $3.5 \%$ & \\
\hline C horizon & $9.4 \%$ & $5.0 \%$ & $2.5 \%$ & $1.0 \%$ & $2.7 \%$ & $1.9 \%$ & \\
\hline
\end{tabular}

* Soil environmental quality - Risk control standard for soil contamination of agricultural land (GB 15618-2018). The different lowercases represent the significant difference of the concentrations along soil profile $(p<0.05)$. 

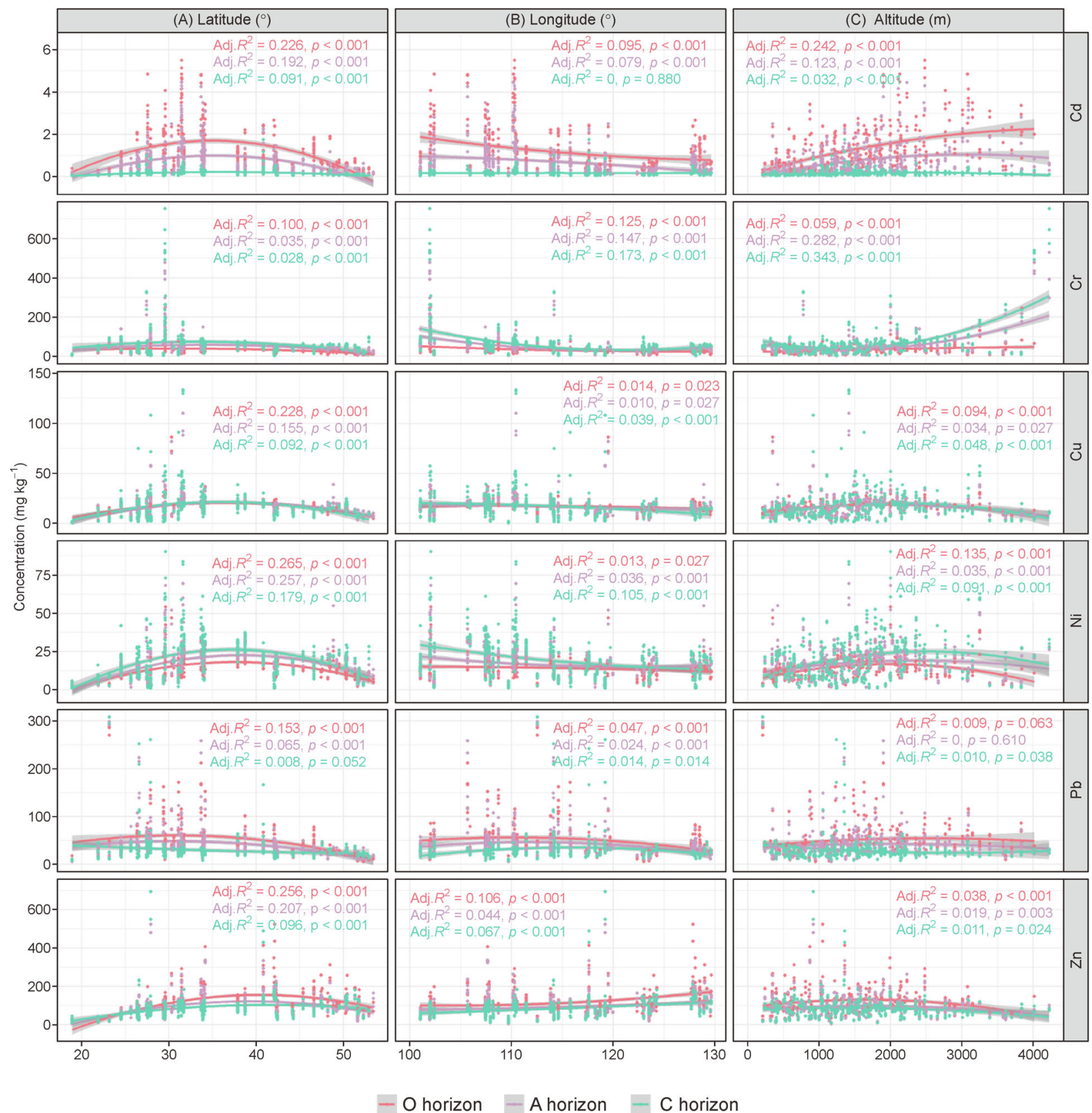

- O horizon - A horizon - C horizon

Fig. 1 The spatial distribution of trace metals in each soil horizon with latitude (A), longitude (B) and altitude (C). The relationships of the metal concentrations with latitude, longitude, and altitude were fitted to better identify the spatial variation in trace metal distribution. $p<0.05$ indicates significant spatial variation.

Zn, which showed an opposite trend. Along the altitude gradient, a significant increase was observed in $\mathrm{Cd}$ and $\mathrm{Cr}$ in the $\mathrm{O}$ and $\mathrm{A}$ horizons, while the concentrations of other metals were relatively higher at medium altitudes, such as 1000 $2000 \mathrm{~m}$ for $\mathrm{Pb}$.

\subsection{The contamination of trace metals in the mountain soils}

The contamination of soil with trace metals indicated by the $I_{\text {geo }}$ showed a decreasing trend with soil depth, except for $\mathrm{Cr}$ and $\mathrm{Ni}$ (Table 2). According to the geological background of each province, Cd displayed a moderate-heavy contamination in the $\mathrm{O}$ horizon and a moderate contamination in the $\mathrm{A}$ horizon, and $\mathrm{Pb}$ reached an uncontaminated-moderate contamination in the $\mathrm{O}$ horizon. Otherwise, the soils were not contaminated by other metals across soil layers. After normalizing the data based on the local background in the $C$ horizon, similar results were observed for the contamination of each metal in the $\mathrm{O}$ and $\mathrm{A}$ horizons, although the $I_{\text {geo }}$ values were a little lower than those calculated using the province 
Table 2 The contamination characteristics (mean \pm standard error) of trace metals indicated by geoaccumulation index ( $\left.I_{g e o}\right)$ in the soils. Proportions of the sites located in the classification standard of the $I_{\text {geo }}$ were also shown.

\begin{tabular}{|c|c|c|c|c|c|c|}
\hline & $\mathrm{Cd}$ & $\mathrm{Cr}$ & $\mathrm{Cu}$ & $\mathrm{Ni}$ & $\mathrm{Pb}$ & $\mathrm{Zn}$ \\
\hline \multicolumn{7}{|c|}{$I_{\text {geo }}$ calculated based on the province background } \\
\hline O horizon & $2.53 \pm 0.07^{a}$ & $-1.81 \pm 0.05^{c}$ & $-1.20 \pm 0.03^{a}$ & $-1.91 \pm 0.04^{b}$ & $0.15 \pm 0.05^{a}$ & $-0.08 \pm 0.05^{a}$ \\
\hline A horizon & $1.60 \pm 0.06^{\mathrm{b}}$ & $-1.32 \pm 0.05^{b}$ & $-1.34 \pm 0.04^{\mathrm{a}}$ & $-1.66 \pm 0.04^{\mathrm{a}}$ & $-0.15 \pm 0.04^{b}$ & $-0.44 \pm 0.04^{b}$ \\
\hline C horizon & $-0.25 \pm 0.06^{\mathrm{c}}$ & $-1.07 \pm 0.05^{\mathrm{a}}$ & $-1.51 \pm 0.05^{b}$ & $-1.52 \pm 0.05^{a}$ & $-0.59 \pm 0.03^{c}$ & $-0.61 \pm 0.04^{c}$ \\
\hline
\end{tabular}

$I_{\text {geo }}$ calculated based on the background in the $\mathrm{C}$ horizon (local background)

$\begin{array}{lllllll}\text { O horizon } & \mathbf{2 . 3 1} \pm \mathbf{0 . 0 6 ^ { \mathrm { a } }} & -1.38 \pm 0.04^{\mathrm{b}} & -0.40 \pm 0.04 & -1.04 \pm 0.04^{\mathrm{b}} & \mathbf{0 . 1 7} \pm \mathbf{0 . 0 4 ^ { \mathrm { a } }} & -0.07 \pm 0.03^{\mathrm{a}} \\ \text { A horizon } & \mathbf{1 . 2 7} \pm \mathbf{0 . 0 5 ^ { \mathrm { b } }} & -0.83 \pm 0.03^{\mathrm{a}} & -0.41 \pm 0.03 & -0.72 \pm 0.03^{\mathrm{a}} & -0.14 \pm 0.03^{\mathrm{b}} & -0.41 \pm 0.02^{\mathrm{b}}\end{array}$

Proportions of samples locating in the classification standard of $I_{\text {geo }}$ (local background)

O horizon

\begin{tabular}{|c|c|c|c|c|c|c|}
\hline$I_{g e o} \leqslant 0$ & $2.3 \%$ & $97.2 \%$ & $80.0 \%$ & $92.6 \%$ & $39.9 \%$ & $57.8 \%$ \\
\hline $0<I_{g e o} \leqslant 1$ & $7.9 \%$ & $1.8 \%$ & $13.6 \%$ & $6.4 \%$ & $44.3 \%$ & $37.6 \%$ \\
\hline $1<I_{g e o} \leqslant 2$ & $29.4 \%$ & $0.5 \%$ & $4.9 \%$ & $0.5 \%$ & $14.3 \%$ & $4.6 \%$ \\
\hline $2<I_{g e o} \leqslant 3$ & $35.3 \%$ & $0.5 \%$ & $1.5 \%$ & $0.3 \%$ & $1.5 \%$ & \\
\hline $3<I_{g e o} \leqslant 4$ & $18.9 \%$ & & & $0.2 \%$ & & \\
\hline $4<I_{g e o} \leqslant 5$ & $5.7 \%$ & & & & & \\
\hline$I_{g e o}>5$ & $0.5 \%$ & & & & & \\
\hline \multicolumn{7}{|l|}{ A horizon } \\
\hline$I_{g e o} \leqslant 0$ & $11.8 \%$ & $94.3 \%$ & $80.6 \%$ & $93.0 \%$ & $63.1 \%$ & $83.3 \%$ \\
\hline $0<I_{\text {geo }} \leqslant 1$ & $32.6 \%$ & $4.3 \%$ & $16.7 \%$ & $5.6 \%$ & $31.4 \%$ & $15.7 \%$ \\
\hline $1<I_{g e o} \leqslant 2$ & $30.7 \%$ & $0.6 \%$ & $2.5 \%$ & $0.6 \%$ & $4.7 \%$ & $1.0 \%$ \\
\hline $2<I_{g e o} \leqslant 3$ & $17.3 \%$ & $0.2 \%$ & $0.2 \%$ & $0.6 \%$ & $0.8 \%$ & \\
\hline $3<I_{\text {geo }} \leqslant 4$ & $6.8 \%$ & $0.6 \%$ & & $0.2 \%$ & & \\
\hline $4<I_{g e o} \leqslant 5$ & $0.8 \%$ & & & & & \\
\hline
\end{tabular}

The different lowercases represent the significant difference of the indices along soil profile $(p<0.05)$.

Note: The classification of $I_{\text {geo }}$ is uncontaminated $\left(I_{\text {geo }} \leqslant 0\right)$, uncontaminated to moderately contaminated $\left(0<I_{\text {geo }} \leqslant 1\right)$, moderately contaminated $\left(1<I_{\text {geo }} \leqslant 2\right)$, moderately to heavily contaminated $\left(2<I_{\text {geo }} \leqslant 3\right)$, heavily contaminated $\left(3<I_{\text {geo }} \leqslant 4\right)$, heavily to extremely contaminated $\left(4<I_{\text {geo }} \leqslant\right.$ $5)$, and extremely contaminated $\left(I_{g e o}>5\right)$.

background data. According to local background in the $\mathrm{C}$ horizon, $64.7 \%$ of $O$ horizon samples and $25.1 \%$ of $A$ horizon samples reached the moderate-heavy and heavy-extremely heavy level, respectively, for $\mathrm{Cd}$ contamination, and $15.8 \%$ of O horizon samples and $5.5 \%$ of A horizon samples had a moderate-heavy contamination of $\mathrm{Pb}$. Otherwise, less than $5 \%$ of samples showed at least moderate contamination for other metals, except $\mathrm{Cu}$ in the $\mathrm{O}$ horizon (Table 2).

Nearly all mountains, except Mts. Fanjing (FJ), Leigong (LG), and Shiwandashan (SWD), showed moderate-heavy or heavy-extremely heavy $\mathrm{Cd}$ contamination in the $\mathrm{O}$ and $\mathrm{A}$ horizons using the province background, and 12 mountains had $\mathrm{Cd}$ contamination in the $\mathrm{C}$ horizon (Fig. 2A). After calibrating using local background level, although all mountains showed $\mathrm{Cd}$ contamination in the $\mathrm{O}$ and $\mathrm{A}$ horizons and
Mts. Ao (AS), Jiugong (JG) and Luoji (LJ) showed heavy contamination in the $\mathrm{O}$ horizon, the contamination level generally decreased (Fig. 2B) when compared with the levels assessed using the province background level (Fig. 2A). For $\mathrm{Pb}$, there was only a moderate-heavy contamination in the $\mathrm{O}$ and A horizons of Mt. Jifeng (JF) and a moderate contamination in the $O$ horizon of Mts. Gongga (GG) and FJ was observed using the provincial background level. Otherwise, $\mathrm{Pb}$ showed uncontaminated-moderate contamination levels (Fig. 2A). Based on local background level, the moderate contamination of $\mathrm{Pb}$ was only observed in the $O$ and $A$ horizons of Mt. JF and in the O horizon of Mt. JG (Fig. 2B). A moderate $\mathrm{Zn}$ contamination was found in the $\mathrm{O}$ horizon of $\mathrm{Mt}$. Changbai (CB) using the provincial background level, while this contamination was found in the O horizon of Mt. Wuzhi 
(A)
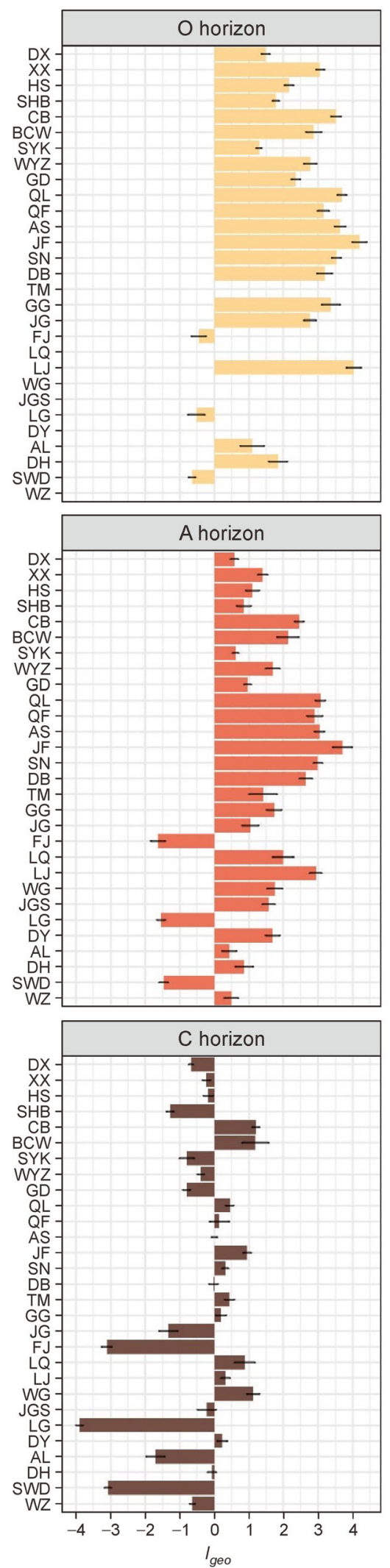

$\mathrm{Pb}$

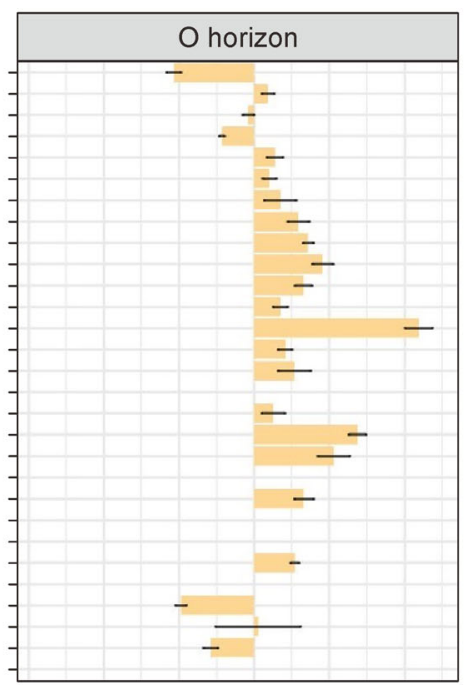

A horizon
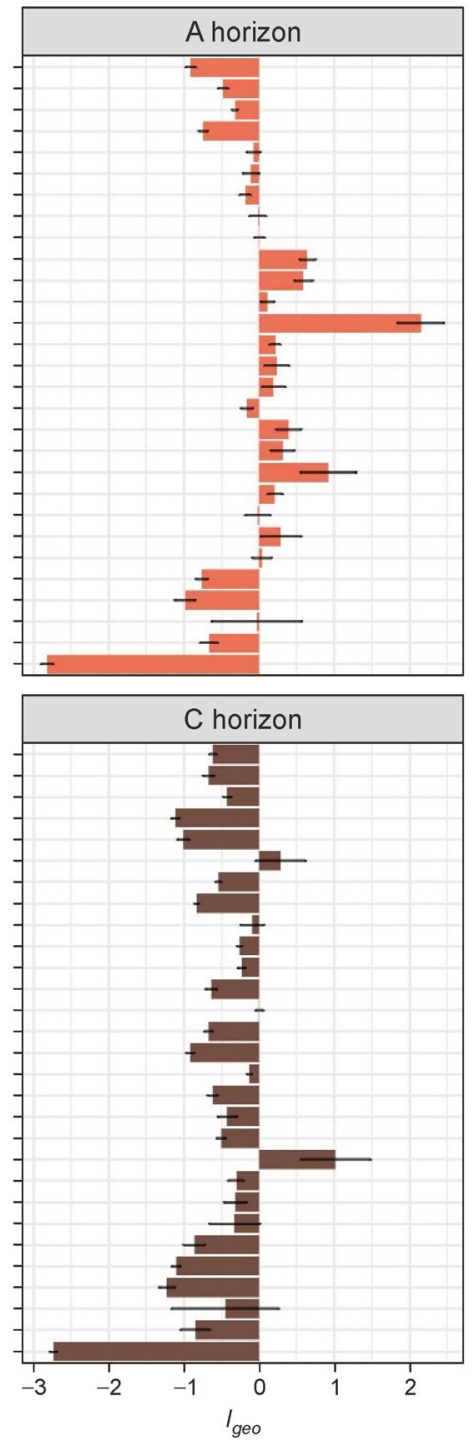
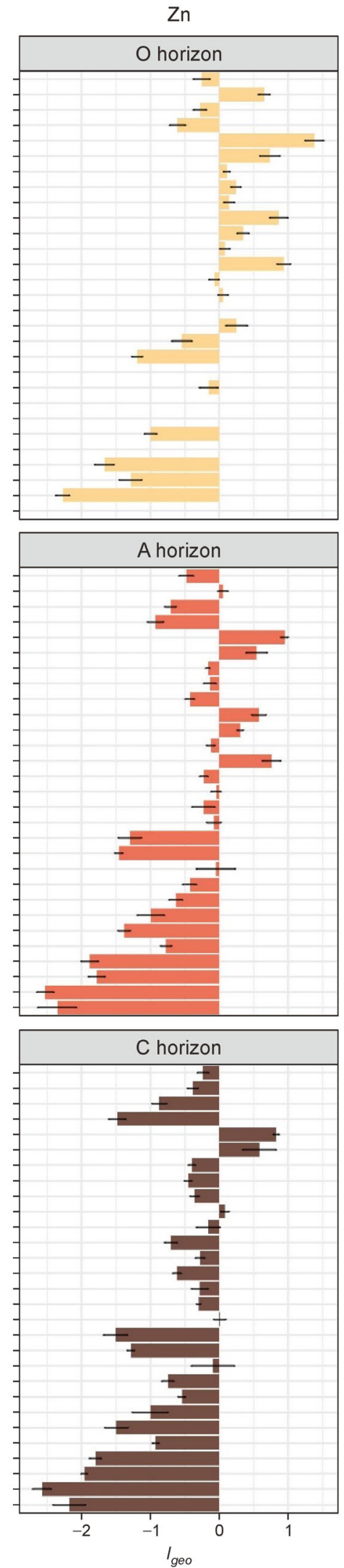
(B)
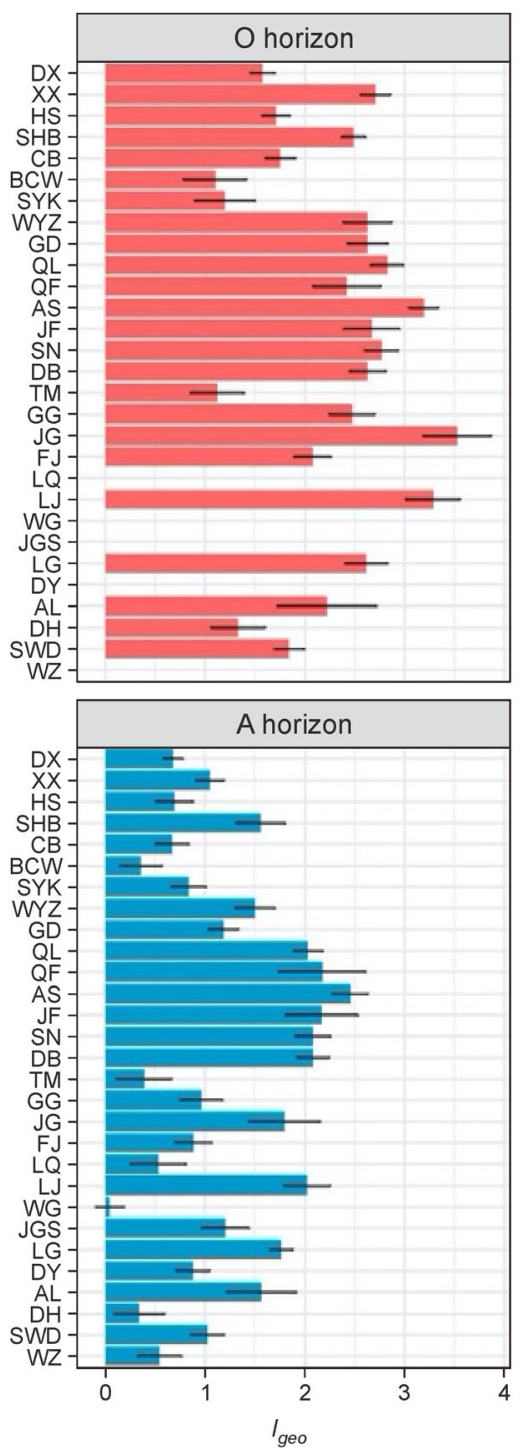

$\mathrm{Pb}$
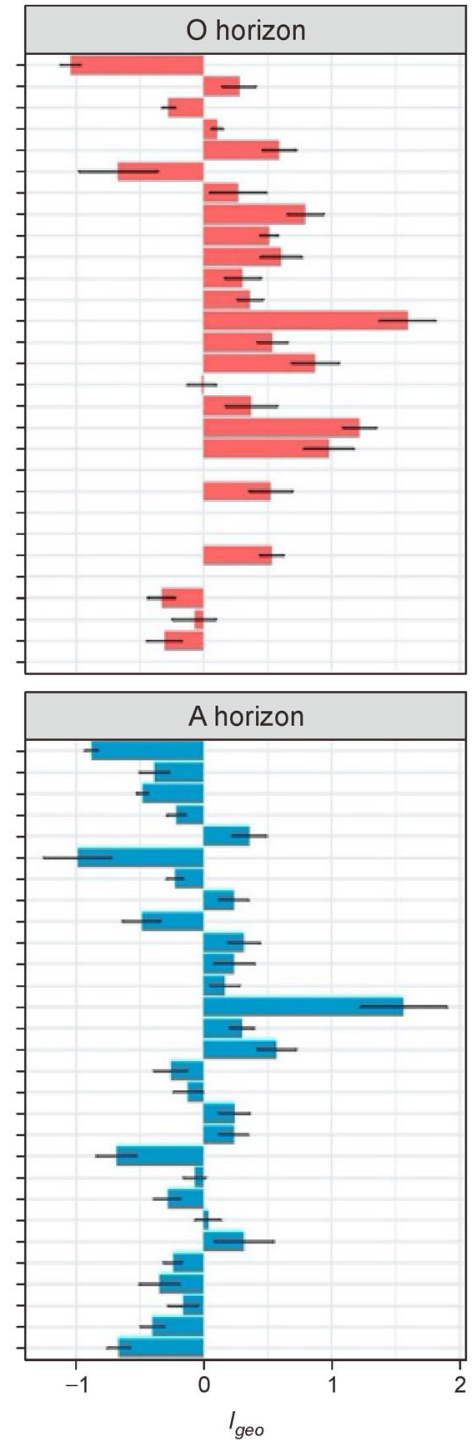

$\mathrm{Zn}$
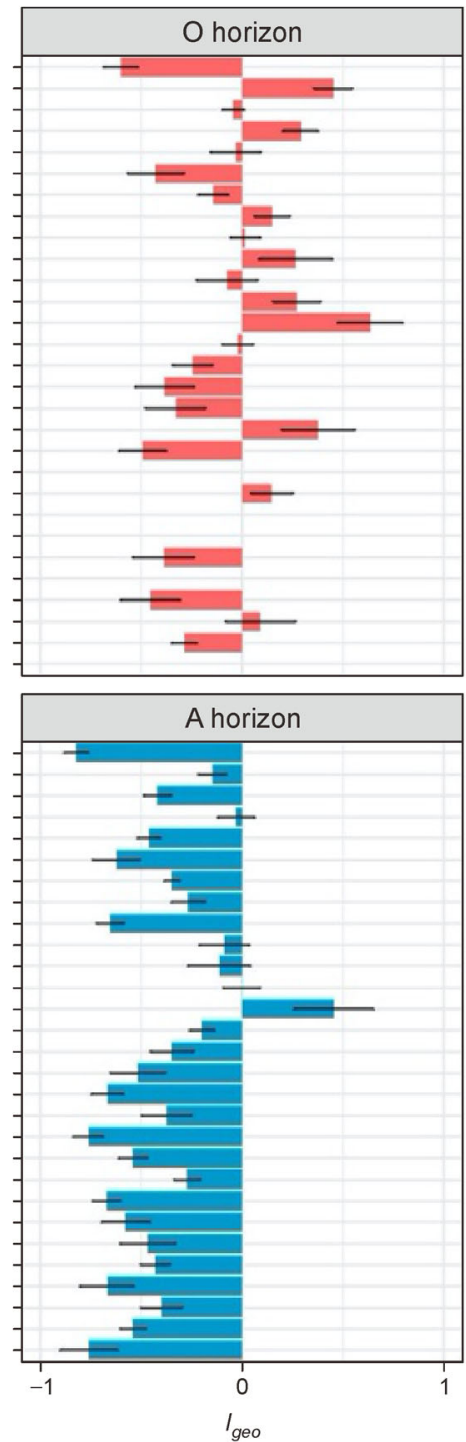

Fig. 2 The contamination characteristics (mean \pm standard error) of $\mathrm{Cd}, \mathrm{Pb}$, and $\mathrm{Zn}$ with depth in each mountain indicated by the geoaccumulation index $\left(I_{g e o}\right)$. The $I_{\text {geo }}$ of other metals can be found in the Supplementary Materials. The values of $I_{g e o}$ in Fig. $2 \mathrm{~A}$ were calculated using the geological background levels of trace metals in each province the mountain was located in, and the values in Fig. 2B were calculated using the local geological background levels of trace metals in the $C$ horizon. The sequence of the mountains from top to bottom in the figure was from north to south China according to the latitude. Note: AL: Mt. Ailao, AS: Mt. Ao, BCW: Mt. Baicaowa, CB: Mt. Changbai, DB: Mt. Dabie, DH: Mt. Dinghu, DX: Daxinganling, DY: Mt. Daiyun, FJ: Mt. Fajing, GD: Mt. Guandi, GG: Mt. Gongga, HS: Mt. Han, JF: Mt. Jifeng, JG: Mt. Jiugong, JGS: Mt. Jinggang, LG: Mt. Leigong, LJ: Mt. Luoji, LQ: Mt. Longquan, QF: Mt. Qingfengxia, QL: Mt. Qinling, SHB: Mt. Saihanba, SN: Mt. Shennongjia, SWD: Mt. Shiwandashan, SYK: Suyukou, TM: Mt. Tianmu, WG: Mt. Wugong, WYZ: Wuyuezhai, WZ: Mt. Wuzhi, XX: Xiaoxinganling.

(WZ) using the local background level. Meanwhile, the number of mountains with $\mathrm{Zn}$ contamination decreased in the $\mathrm{O}$ and $\mathrm{A}$ horizons (Fig. 2). According to provincial background level, no mountains had $\mathrm{Cu}$ contamination (Fig. S2), while several mountains showed uncontaminatedmoderate $\mathrm{Cu}$ contamination in the $\mathrm{O}$ and $\mathrm{A}$ horizons according to local background level (Fig. S2B). The mountain soils were not contaminated by $\mathrm{Cr}$ and $\mathrm{Ni}$ across soil horizons compared with different background levels, except $\mathrm{Cr}$ in the $\mathrm{A}$ and $\mathrm{C}$ horizons of Mt. GG based on provincial background level and $\mathrm{Cr}$ and $\mathrm{Ni}$ in the $\mathrm{A}$ horizon of $\mathrm{Mt}$. $\mathrm{CB}$ based on local background level (Fig. S2). 
3.3 The enrichment characteristics of trace metals in the mountain soils

The trace metal EF decreased significantly with depth, except for $\mathrm{Cr}$ (Table 3). Specifically, Cd generally had a very high enrichment in the $\mathrm{O}$ horizon and a significant enrichment in the A horizon, while $\mathrm{Cu}, \mathrm{Pb}$, and $\mathrm{Zn}$ showed moderate enrichment in the $\mathrm{O}$ horizon, $\mathrm{Pb}$ showed moderate enrichment in the $\mathrm{A}$ horizon, and $\mathrm{Cr}$ and $\mathrm{Ni}$ displayed mineral depletion (Table 3). Moreover, $89.3 \%$ and $42.3 \%$ of $O$ and $A$ horizon samples, respectively, had at least a significant enrichment of Cd, while $10.5 \%, 26.8 \%$, and $19.4 \%$ of O horizon samples reached significant enrichment for $\mathrm{Cu}, \mathrm{Pb}$, and $\mathrm{Zn}$, respectively. Otherwise, the proportion of soil samples exceeding the significant enrichment level was lower than $5 \%$ across soil horizons (Table 3).

Except for Mts. WZ and Wugong (WG), the soil samples from the mountains showed evident $\mathrm{Cd}$ enrichment in the $\mathrm{O}$ and A horizons (Fig. 3). Specifically, four mountains (Mts. LJ, Shennongjia (SN), JF, and AS) had very high Cd enrichment, 14 mountains had significant $\mathrm{Cd}$ enrichment in the $\mathrm{O}$ horizon, and eight mountains had significant enrichment in the $A$ horizon. Otherwise, enrichment was at the moderate level across soil horizons. For $\mathrm{Pb}$, seven and 10 mountains showed significant and moderate enrichment in the $O$ horizon, respectively, and one mountain (Mt. JF) and 10 mountains had significant and moderate $\mathrm{Pb}$ enrichment in the A horizon, respectively. Otherwise, the soils showed depletion of $\mathrm{Pb}$ (Fig. 3). Significant $Z n$ enrichment was only observed in the $O$ horizon of Mts. LJ and JF, and 16 and five mountains showed moderate $\mathrm{Zn}$ enrichment in the $\mathrm{O}$ and $\mathrm{A}$ horizons, respectively. Otherwise, $\mathrm{Zn}$ showed depletion across soil horizons (Fig. 3). There was also depletion of $\mathrm{Cr}, \mathrm{Cu}$, and $\mathrm{Ni}$, expect for Mts. LJ and CB (Fig. S3).

\subsection{The isotopic ratios of lead in the mountain soils}

The isotopic ratios of $\mathrm{Pb}$ varied significantly along the soil profile (mean $\pm \mathrm{SE}, p<0.05$, Table 4 ), with a ${ }^{206} \mathrm{~Pb} /{ }^{207} \mathrm{~Pb}$ of $1.170 \pm 0.001,1.180 \pm 0.001$, and $1.193 \pm 0.002$ and $a$ ${ }^{208} \mathrm{~Pb} /{ }^{206} \mathrm{~Pb}$ of $2.106 \pm 0.001,2.097 \pm 0.001$, and $2.088 \pm$ 0.003 in the $\mathrm{O}, \mathrm{A}$, and $\mathrm{C}$ horizons, respectively. We compared the ratios of ${ }^{206} \mathrm{~Pb} /{ }^{207} \mathrm{~Pb}$ with other studies because of its wide application to trace $\mathrm{Pb}$ sources (Table 4). The results showed that our ratios in the $\mathrm{O}$ and $\mathrm{A}$ horizons were comparable to the ratios found in China's ore deposits, China's fossil fuels and their emissions, such as fly ash and combustion dust, and urban air dusts/aerosols, but they were different from the ratios found in loess and Aeolian dusts in north-west China. Meanwhile, the ${ }^{206} \mathrm{~Pb} /{ }^{207} \mathrm{~Pb}$ ratios in the $\mathrm{O}$ horizon were very close to those of the mosses collected from each mountain. The ${ }^{206} \mathrm{~Pb} /{ }^{207} \mathrm{~Pb}$ ratios in each mountain were mapped to

Table 3 The characteristics of the enrichment factor (EF, mean \pm standard error) of trace metals in the soils. Proportions of the sites located in the classification standard of the EF are also shown.

\begin{tabular}{|c|c|c|c|c|c|c|}
\hline & $\mathrm{Cd}$ & $\mathrm{Cr}$ & $\mathrm{Cu}$ & $\mathrm{Ni}$ & $\mathrm{Pb}$ & $\mathrm{Zn}$ \\
\hline \multicolumn{7}{|c|}{ EF calculated based on the local background } \\
\hline O horizon & $23.38 \pm 1.24^{a}$ & $1.30 \pm 0.05^{a}$ & $3.00 \pm 0.17^{\mathrm{a}}$ & $1.78 \pm 0.09^{a}$ & $4.49 \pm 0.20^{a}$ & $3.55 \pm 0.13^{\mathrm{a}}$ \\
\hline A horizon & $7.17 \pm 0.37^{\mathrm{b}}$ & $1.23 \pm 0.05^{\mathrm{a}}$ & $1.69 \pm 0.06^{\mathrm{b}}$ & $1.33 \pm 0.05^{\mathrm{b}}$ & $2.15 \pm 0.08^{b}$ & $1.64 \pm 0.04^{b}$ \\
\hline \multicolumn{7}{|c|}{ Proportions of samples locating in the classification standard of EFs } \\
\hline \multicolumn{7}{|l|}{ O horizon } \\
\hline $\mathrm{EF}<2$ & $1.5 \%$ & $91.5 \%$ & $45.0 \%$ & $82.4 \%$ & $22.5 \%$ & $29.4 \%$ \\
\hline $2 \leqslant E F<5$ & $9.2 \%$ & $7.7 \%$ & $44.5 \%$ & $14.3 \%$ & $50.7 \%$ & $51.2 \%$ \\
\hline $5 \leqslant E F<20$ & $50.1 \%$ & $0.8 \%$ & $9.7 \%$ & $3.1 \%$ & $25.3 \%$ & $19.4 \%$ \\
\hline $20 \leqslant E F<40$ & $23.6 \%$ & & $0.8 \%$ & $0.2 \%$ & $1.5 \%$ & \\
\hline$E F \geqslant 40$ & $15.6 \%$ & & & & & \\
\hline \multicolumn{7}{|l|}{ A horizon } \\
\hline $\mathrm{EF}<2$ & $17.1 \%$ & $95.9 \%$ & $80.6 \%$ & $91.8 \%$ & $65.0 \%$ & $79.8 \%$ \\
\hline $2 \leqslant E F<5$ & $40.6 \%$ & $3.1 \%$ & $17.3 \%$ & $6.6 \%$ & $30.1 \%$ & $18.6 \%$ \\
\hline $5 \leqslant E F<0$ & $35.1 \%$ & $1.0 \%$ & $2.1 \%$ & $1.6 \%$ & $4.7 \%$ & $1.6 \%$ \\
\hline $20 \leqslant E F<40$ & $5.8 \%$ & & & & $0.2 \%$ & \\
\hline$E F \geqslant 40$ & $1.4 \%$ & & & & & \\
\hline
\end{tabular}

The different lowercases represent the significant difference of the indices along soil profile $(p<0.05)$.

Note: The classification of EF is depletion to mineral enrichment (EFs $<2)$, moderate enrichment $(2 \leqslant E F s<5)$, significant enrichment $(5 \leqslant E F s<$ $20)$, very high enrichment $(20 \leqslant E F s<40)$, and extremely high enrichment $(E F s \geqslant 40)$. 

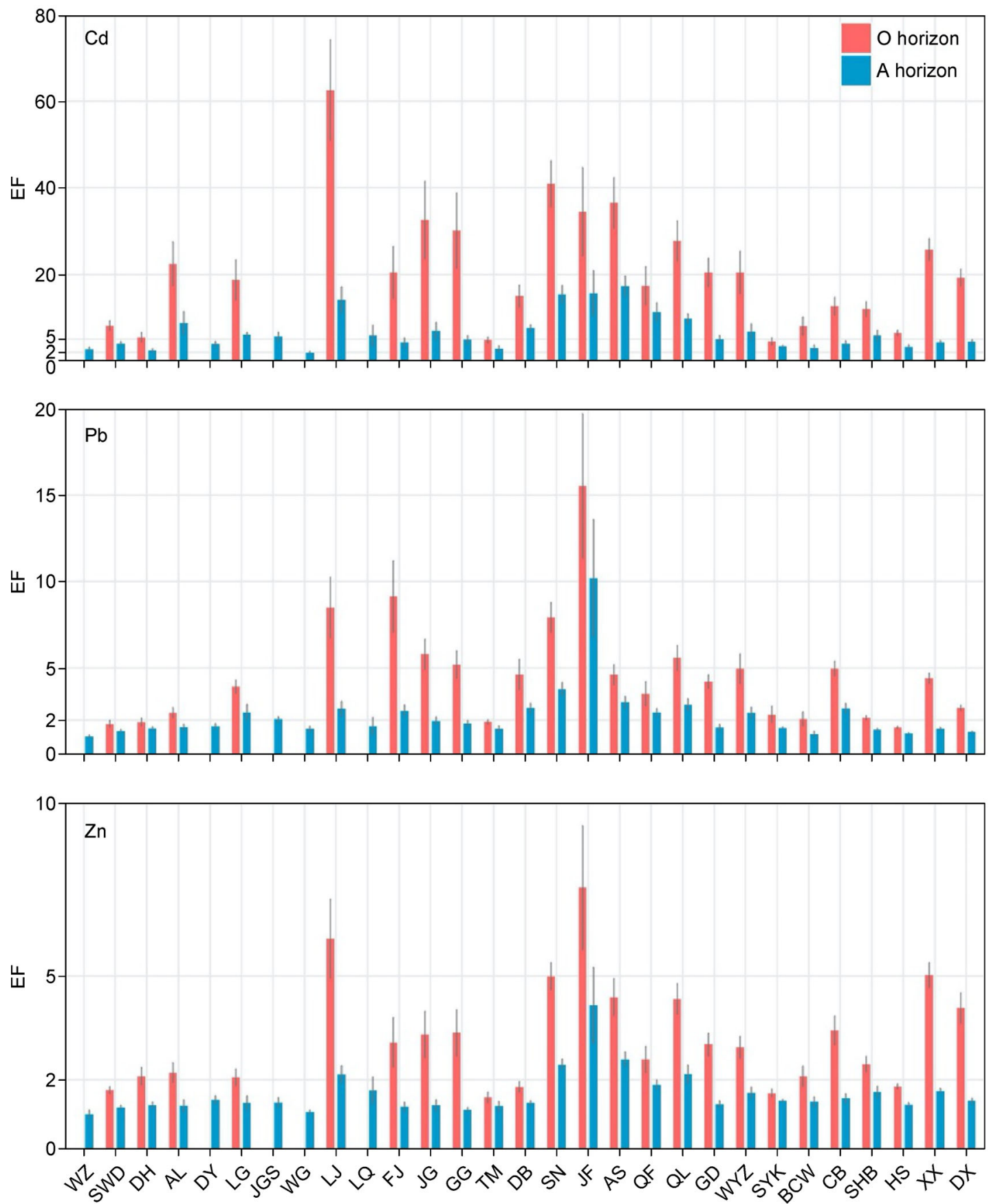

Fig. 3 The enrichment characteristics (mean \pm standard error) of $\mathrm{Cd}, \mathrm{Pb}$, and $\mathrm{Zn}$ in the $\mathrm{O}$ and $\mathrm{A}$ horizons of each mountain indicated by the index of enrichment factor $(E F)$. The $E F$ of other metals can be found in the Supplementary Materials. Note that the numbers in the $Y$ axis indicate the enrichment level of the metal according to the classification standard of the $E F$. The sequence of the mountains from left to right in the figure was from south to north China according to the latitude. The specific mountain names can be found in Fig. 2.

further investigate the spatial differences (Fig. S4). It was evident that most of the ratios in the $\mathrm{O}$ and $\mathrm{A}$ horizons were located in the range of 1.16-1.18 and below 1.16. However, in the $\mathrm{C}$ horizon, most of mountains had ratios above 1.18, and four mountains (Mts. CB, Baicaowa [BCW], LG, and Dabie [DB]) had ratios in the range of 1.16-1.18 or below 1.16.
Two-dimensional diagrams of ${ }^{206} \mathrm{~Pb} /{ }^{207} \mathrm{~Pb}$ versus ${ }^{208} \mathrm{~Pb} /{ }^{206} \mathrm{~Pb}$ can indicate the difference in the $\mathrm{Pb}$ isotopic composition of different archives and soil horizons. Our previous study compiled a large data set of $\mathrm{Pb}$ isotopic ratios in China's mountain mosses and potential source materials in China, including polymetallic ores, coal, fuel combustion 
Table 4 The ratios of ${ }^{206} \mathrm{~Pb} /{ }^{207} \mathrm{~Pb}$ (mean \pm standard error) in China's mountain soils compared with the ratios in other potential source materials.

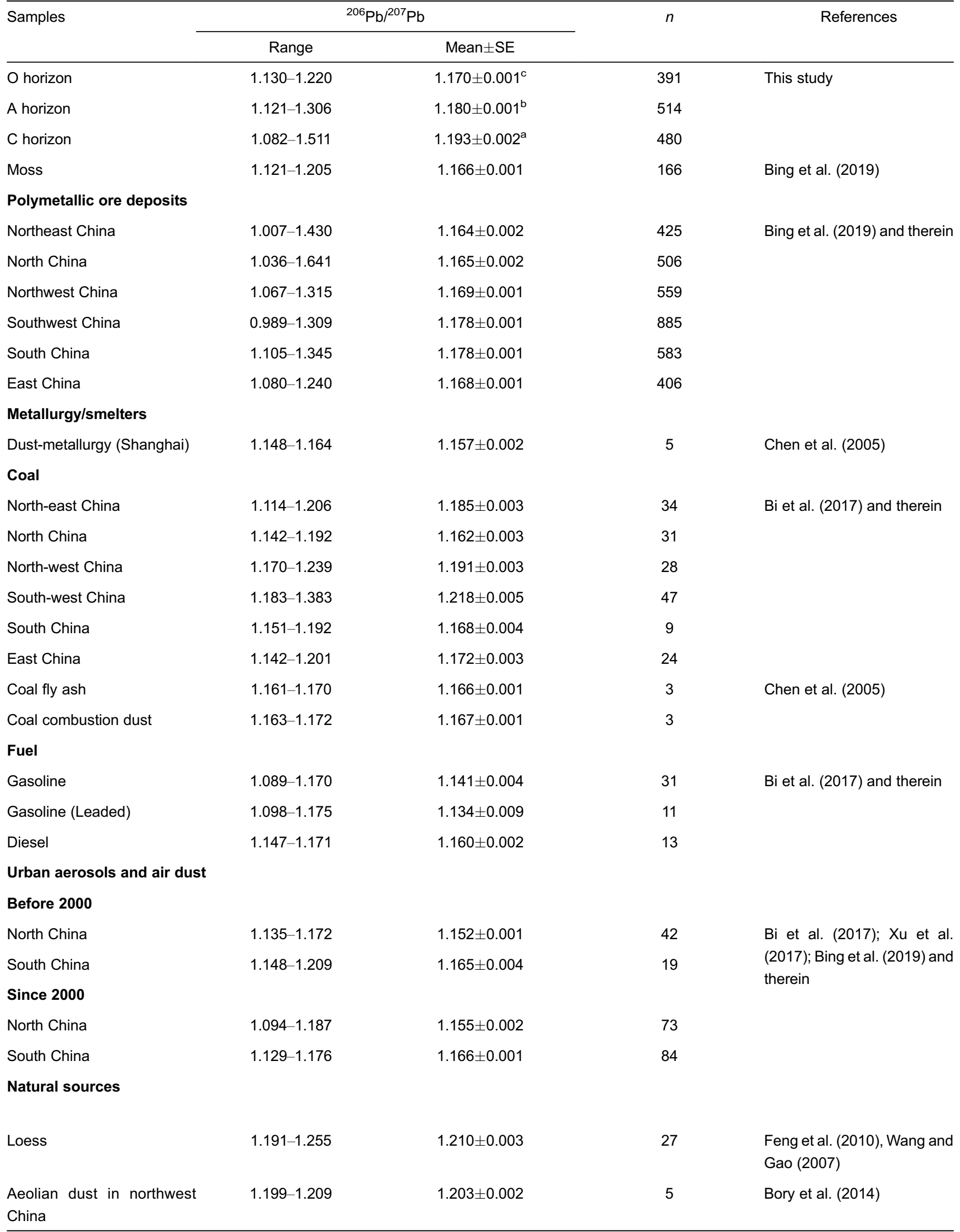


emissions, air dusts/aerosols, vehicle exhaust, and Chinese loess (Bing et al., 2019 and references therein). According to this data set, we observed several characteristics of $\mathrm{Pb}$ isotopic ratios in the soils. First, the ratios of ${ }^{206} \mathrm{~Pb} /{ }^{207} \mathrm{~Pb}$ and ${ }^{208} \mathrm{~Pb} /{ }^{206} \mathrm{~Pb}$ were significantly correlated, indicating two endmembers of soil $\mathrm{Pb}$ sources (Fig. 4A). Second, despite a broad range of the ratios (especially in the $C$ horizon), the values in the $O$ and $A$ horizons were relatively constrained, indicating a similar source (Fig. 4). Third, the ratios in the $\mathrm{O}$ and $A$ horizons overlapped with those in mosses, polymetallic ores, coals, fuel combustion emissions, and air dusts/ aerosols, but they were markedly different from those in Chinese loess (Fig. 4B). Lastly, most of the ratios of ${ }^{206} \mathrm{~Pb} /{ }^{207} \mathrm{~Pb}$ and ${ }^{208} \mathrm{~Pb} /{ }^{206} \mathrm{~Pb}$ in the $\mathrm{C}$ horizon were close to those in loess, except for Mts. BCW, CB, DB, and LG, which had lower ${ }^{206} \mathrm{~Pb} /{ }^{207} \mathrm{~Pb}$ and higher ${ }^{208} \mathrm{~Pb} /{ }^{206} \mathrm{~Pb}$ ratios than those of loess (Fig. 4B and Fig. S4).

\subsection{Relationships of trace metals with environmental factors}

The BRT analysis showed the potential factors or predictors contributing to changes in the distribution of trace metals in the mountain soil samples (Fig. 5). The results showed that different variables influenced the concentrations of different trace metals. In the $\mathrm{O}$ horizon, $\mathrm{Cd}$ was primarily influenced by climate (MAT and MAP) and atmospheric nitrogen deposition (At_DIN), followed by SOC and altitude; Cr was dominantly affected by At_DIN and SOC; $\mathrm{Cu}$ and $\mathrm{Ni}$ were mainly influenced by soil $\mathrm{pH}$, climate and At_DIN; Pb was influenced by climate and At_DIN, with similar contribution of other factors; $\mathrm{Zn}$ was mainly regulated by climate, followed by soil
$\mathrm{pH}$, and then NDVI and At_DIN. In the A horizon, climate primarily influenced the distribution of all trace metals in the soils. Otherwise, the trace metals were influenced by SOC for Cd, by CIA, SOC and NDVI for $\mathrm{Cr}$, by soil $\mathrm{pH}$ and CIA for $\mathrm{Cu}$ and $\mathrm{Ni}$, by At_DIN for $\mathrm{Pb}$, and by NDVI, soil $\mathrm{pH}$ and CIA for $\mathrm{Zn}$. Besides climate, SOC, soil $\mathrm{pH}, \mathrm{CIA}$, and NDVI primarily affected the trace metals in the $\mathrm{C}$ horizon. Compared with the factors above, altitude (except for $\mathrm{Cd}$ ) and $\mathrm{pH}$ in rainfall had a limited effect on the metals across soil horizons.

\section{Discussion}

4.1 The contamination and spatial distribution of trace metals in the mountain soils

The mountain critical zone is commonly far from urban populations and industrial centers, and it is regarded as a "clean" area without trace metal contamination (Chen et al., 2015). In this study, we observed significantly higher concentrations of $\mathrm{Cd}$ and comparable concentrations of $\mathrm{Pb}$ and $\mathrm{Zn}$ in surface soils than urban and agricultural soils (Table 1). Meanwhile, the contamination assessment revealed that a large proportion of soil samples had substantial contamination of $\mathrm{Cd}$ and $\mathrm{Pb}$ : heavy-extremely heavy contamination levels of $\mathrm{Cd}$ were found for many mountains (Table 2, Fig. 2). This result is in accordance with other reports that mention that $\mathrm{Cd}$ is the priority metal requiring control in China's soils (Teng et al., 2014; Chen et al., 2015; Zhao et al., 2015; Huang et al., 2019). When assessing the contamination of a metal in soils at a large scale, the uniform background
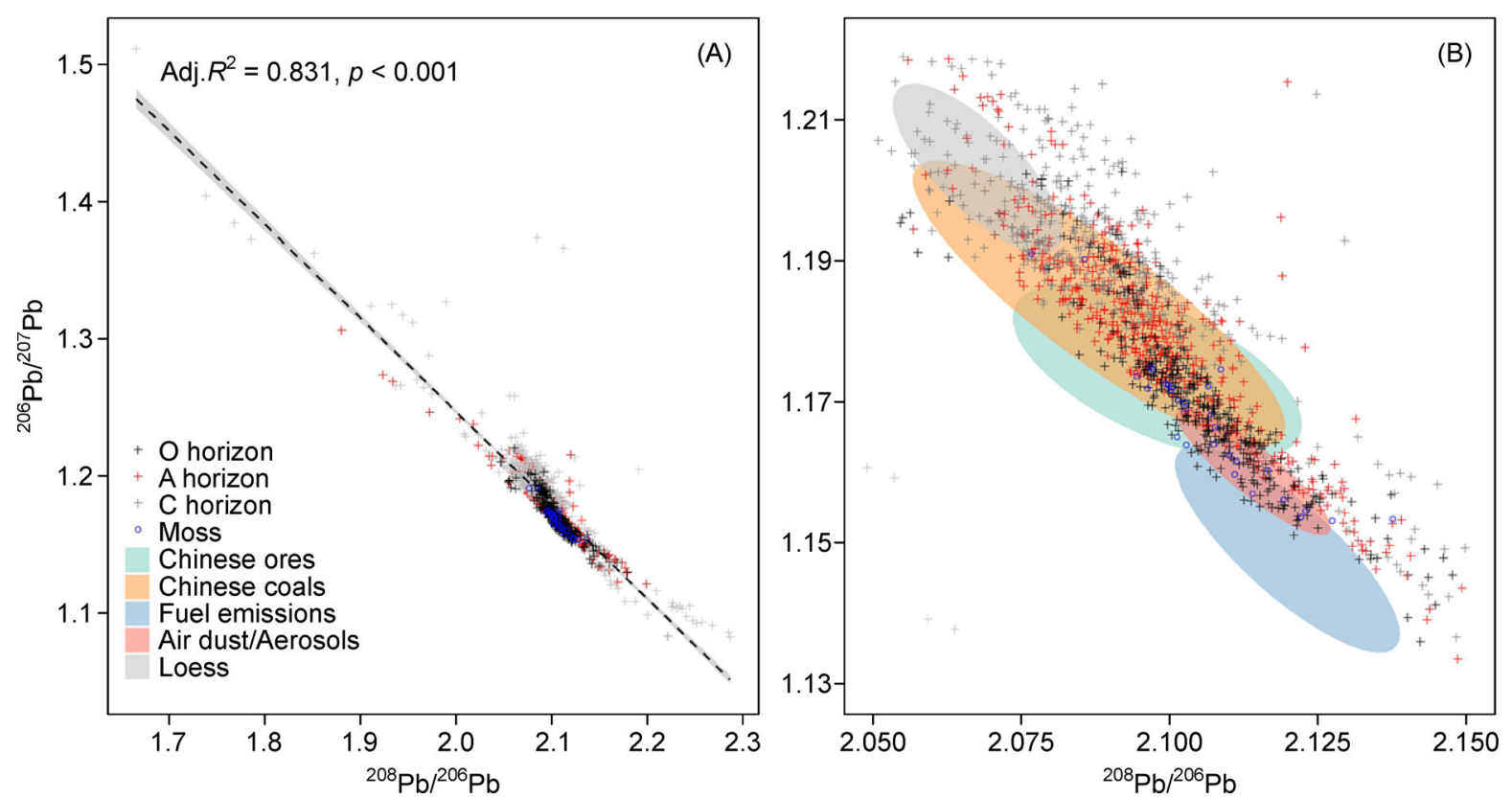

Fig. 4 The diagrams of ${ }^{206} \mathrm{~Pb} /{ }^{207} \mathrm{~Pb}$ versus ${ }^{208} \mathrm{~Pb} /{ }^{206} \mathrm{~Pb}$ in each soil horizon and for other materials, including the mosses from each mountain. Figure $4 \mathrm{~A}$ shows all isotopic ratios of $\mathrm{Pb}$ in the mountain soils, and Fig. $4 \mathrm{~B}$ highlights the anthropogenic endmember of $\mathrm{Pb}$ according to the isotopic ratios. The $\mathrm{Pb}$ isotopic data in other materials have been compiled in our previous study (Bing et al., 2019 and references therein), and some references can be found in Table 4 . 

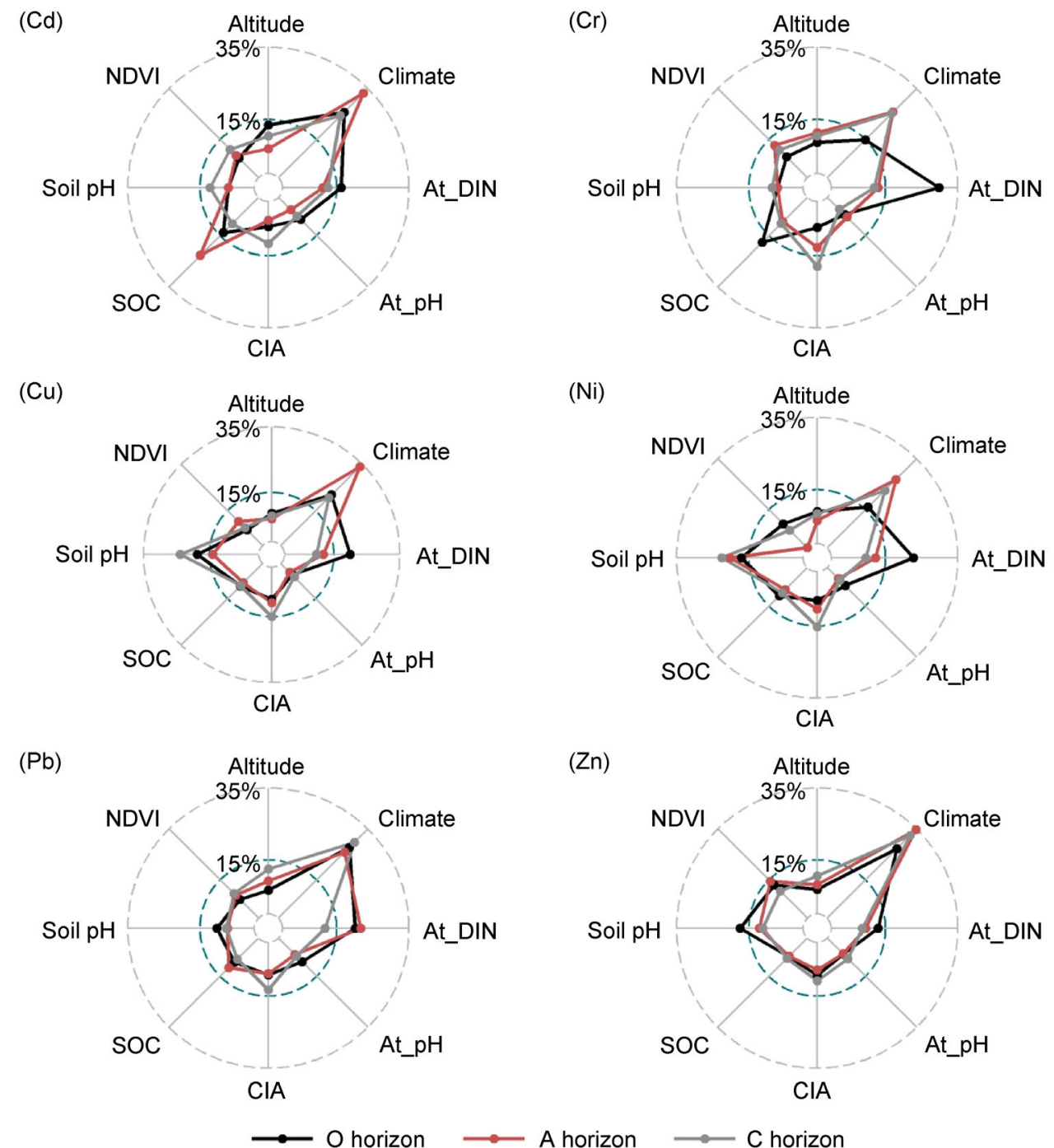

Fig. 5 The relative contributions (\%) of potential factors in explaining the variations in trace metals in each soil horizon based on boosted regression tree analysis. NDVI, normalized difference vegetation index; Climate, the sum of MAT (mean annual temperature) and MAP (mean annual precipitation); At_DIN, atmospheric inorganic nitrogen deposition; At_pH, pH in rainfall; CIA, chemical index of alteration; and SOC, soil organic carbon.

level of the metal has been widely applied (Hu et al., 2020; $\mathrm{Li}$ et al., 2020). However, this method could overestimate or underestimate the contamination of some metals in soils because of spatial variation in regional parent materials (Reimann et al., 2015; Hou et al., 2020). Our results showed that using provincial background levels to assess the contamination of trace metals in mountain soils overestimated the $\mathrm{Cd}$ contamination and underestimated the contamination levels of $\mathrm{Cr}, \mathrm{Cu}$, and $\mathrm{Ni}$, but it did not affect the results for $\mathrm{Pb}$ and $\mathrm{Zn}$ (Table 2). Thus, it is recommended to consider using local background levels of trace metals when assessing the contamination of soil trace metals in a large-scale study.

The spatial distribution of trace metals in the surface soils of China's mountains showed a parabolic trend with latitude and a decreasing trend with increasing longitude (except Zn, Fig. 1 and Fig. S1), which indicates that relatively high concentra- tions of trace metals exist in northwest, southwest, and south China relative to east, north, and northeast China. This is partially consistent with the distribution patterns of trace metals in the soils of agricultural, urban, and mining areas. For example, Huang et al. (2019) and Niu et al. (2013) revealed that the contents of trace metals in farmland soils were generally higher in southwest and central China as well as southern coastal areas, but they were lower in north-west China. Chen et al. (2015) reported that the contamination of trace metals in China's soils was higher in southwest and south-central China and eastern coastal regions, while there was low contamination in northwest China. Li et al. (2014) reported that the contamination of trace metals in mining soils was higher in south and east China. Additionally, Yang et al. (2018) found the contamination of trace metals in industrial and agricultural soils was higher in southeast China than 
northwest China. These spatial differences were related to the higher geochemical background in the southwestern regions and increasing human activities in the southeastern areas of China. However, our study presented some discrepancies and opposite trends in the distribution of trace metals in China's mountain soils: we found higher concentrations of trace metals in northwest China and lower concentrations of trace metals in east China. The mountain regions of China are relatively less disturbed by human activities, and the distribution of trace metals in these soils could be driven by different factors, such as sources, climate, vegetation, and soil properties, which will be specifically discussed below.

\subsection{Source identification of trace metals in the mountain soils}

The sources of trace metals in mountain regions include natural and anthropogenic origins. Because of remote geographic location of mountains, the anthropogenic sources of trace metals are primarily dry and wet deposition by longrange transboundary atmospheric transport, (Bing et al., 2018). In this study, we found significant contamination of $\mathrm{Cd}$ and slight to moderate contamination of $\mathrm{Pb}$ in surface soils (or $\mathrm{Zn}$ in some mountains, Table 2, Fig. 2B and Fig. S2B). The marked enrichment of these metals in the soils was also observed after calibration using local background levels of metals (Table 3, Fig. 3). This indicates that there are external inputs of $\mathrm{Cd}$ and $\mathrm{Pb}$ (and $\mathrm{Zn}$ in certain mountains) in surface soils. The increase in $\mathrm{Cd}$ concentrations in surface soils with altitude supports the theory that long-distance atmospheric transport probably contributes to $\mathrm{Cd}$ deposition at high altitudes under the effect of cold condensation. Furthermore, the concentrations of $\mathrm{Cd}$ and $\mathrm{Pb}$ and the ratios of ${ }^{206} \mathrm{~Pb} /{ }^{207} \mathrm{~Pb}$ in the $\mathrm{O}$ and $\mathrm{A}$ horizons were significantly correlated with those in mosses (Fig. S5), which further confirms that atmospheric deposition results in the accumulation of $\mathrm{Cd}$ and $\mathrm{Pb}$ in soils. In agreement with our results, Zhu et al. (2016) also reported that the $\mathrm{Cd}$ and $\mathrm{Pb}$ contents in wet deposition were positively related to concentrations in the soils from China's natural terrestrial ecosystems, indicating their atmospheric source. All this evidence suggests that $\mathrm{Cd}$ and $\mathrm{Pb}$ in the soils of China's mountains suffer from atmospheric deposition, possibly from long-range atmospheric transport.

In contrast to $\mathrm{Cr}, \mathrm{Cu}$, and $\mathrm{Ni}$, there was an extremely significant correlation between $\mathrm{Cd}$ and $\mathrm{Pb}$ in the soils (Table S3), suggesting that they have similar external sources. Thus, we used $\mathrm{Pb}$ isotopic ratios to trace the specific sources of $\mathrm{Pb}$ in the soils. In China, atmospheric $\mathrm{Pb}$ emissions have changed in the last few decades, and ore mining, nonferrous metal smelting, and coal combustion have become the major sources of emissions (Li et al., 2012; Cheng et al., 2015; Bi et al., 2017). Commonly, a ${ }^{206} \mathrm{~Pb} /{ }^{207} \mathrm{~Pb}$ ratio between 1.16 and 1.18 indicate $\mathrm{Pb}$ sources from Chinese ore mining, nonferrous smelting, and coal combustion emissions, ratios $>1.18$ indicate natural sources, while ratios $<1.16$ indicate anthropogenic contributions, such as vehicle emissions, air dusts/ aerosols, and other fuel combustion (Table 4). Our results suggest that the $\mathrm{Pb}$ sources in the $\mathrm{O}$ and $\mathrm{A}$ horizons are primarily from resource exploitation and energy consumption and those in the $\mathrm{C}$ horizon are from parent weathering. In support of this viewpoint, there were more mountains in north China with ${ }^{206} \mathrm{~Pb} /{ }^{207} \mathrm{~Pb}$ ratios of $1.16-1.18$ in the $O$ and $A$ horizons (Fig. S4), indicating the contribution of fossil fuel combustion for traditional heating in winter. Unexpectedly, the ${ }^{206} \mathrm{~Pb} /{ }^{207} \mathrm{~Pb}$ ratios were very low in the $\mathrm{C}$ horizon of Mts. BCW, $\mathrm{CB}$, and $\mathrm{DB}$. It is not evident that the $\mathrm{C}$ horizon soils were contaminated by $\mathrm{Pb}$ or other metals because of the low concentrations and $I_{\text {geo }}$ values that were found (Table 2). In contrast, some $\mathrm{Pb}$-containing ores could exist in these mountains, which usually have lower ${ }^{206} \mathrm{~Pb} /{ }^{207} \mathrm{~Pb}$ ratios. This would support the theory that natural $\mathrm{Pb}$ in the $\mathrm{O}$ and $\mathrm{A}$ horizons of these mountains is mixed with anthropogenic $\mathrm{Pb}$ with a relatively higher ${ }^{206} \mathrm{~Pb} /{ }^{207} \mathrm{~Pb}$ (Fig. S4).

The trends found in the two-dimensional diagrams of ${ }^{206} \mathrm{~Pb} /{ }^{207} \mathrm{~Pb}$ and ${ }^{208} \mathrm{~Pb} /{ }^{206} \mathrm{~Pb}$ further confirmed the anthropogenic sources of $\mathrm{Pb}$ along the soil profile. However, the $\mathrm{Pb}$ isotopic ratios in the soils were markedly different from those found in vehicle exhausts, which suggests that $\mathrm{Pb}$-containing gasoline is not a major source of $\mathrm{Pb}$ in the atmosphere of remote areas because of its phasing-out since 2000 in China (Bi et al., 2017). Meanwhile, the $\mathrm{Pb}$ ratios in the sampled mountain soils did not entirely fall within the ranges of the data set compiled for different sources (Fig. 4). This indicates that it is not easy to distinguish the specific sources of trace metals in mountain regions, primarily because of the complex and mixed anthropogenic sources during long-range transboundary atmospheric transport. However, our isotopic ratios identified atmospheric and anthropogenic $\mathrm{Pb}$ in most $\mathrm{O}$ and A horizons based on the ratios in mosses and air dusts/ aerosols, which are effective and direct indicators of atmospheric pollution (Harmens et al., 2010; Hou et al., 2019; Luo et al., 2019).

\subsection{Potential drivers of trace metal accumulation in the mountain soils}

Soil development and soil properties, such as soil pH and soil organic matter (SOM), are recognized as important factors influencing the distribution of trace metals in soils (Bearup et al., 2014; Bing et al., 2016c; Tian et al., 2018; Bińczycki et al., 2020). For example, SOM has a strong capacity for adsorption and complexation with trace metals, and then, it reduces their mobility, which can be supported by the positive relationship between $\mathrm{Cd}$ and SOC. In contrast, the negative relationship between $\mathrm{Cd}$ and soil $\mathrm{pH}$ indicates that a decrease in soil $\mathrm{pH}$ will increase the mobilization of trace metals in soils through the acidification effect. Our study revealed that SOC had significant effects on $\mathrm{Cd}, \mathrm{Cr}$, and $\mathrm{Pb}$, and soil $\mathrm{pH}$ determined the distribution of $\mathrm{Cu}, \mathrm{Ni}$, and $\mathrm{Zn}$ in the $\mathrm{O}$ and $\mathrm{A}$ horizons (Fig. 5). However, further research is required on the net effects of SOM versus $\mathrm{pH}$ on the fate of trace metals under 
scenarios of climate warming and/or acid deposition. Moreover, soil weathering or formation can determine the distribution of trace metals in the soil profile. The close relationship between trace metals and CIA supports the key role of soil weathering in metal accumulation, especially in the $C$ horizon (Fig. 5). Meanwhile, the results of enrichment factor, which eliminates the effect of the geological background and reflects the enrichment characteristic of metals along soil profile, further confirm that, except for $\mathrm{Cd}$, the trace metals in the soils of most mountains were determined by the soil parent materials at the location. This is also in agreement with other studies, which found that the local geological background determined the distribution of trace metals in soils (Huang et al., 2019; Hou et al., 2020; Zhao et al., 2020).

Despite the direct control of soil properties and parent materials, climate (MAT and MAP), atmospheric deposition, altitude, and vegetation played important roles in the distribution of trace metals in the mountain soils (Fig. 5). This finding is in agreement with research that has found that there are close relationships between altitude, local climate, and vegetation type in alpine ecosystems (Stankwitz et al., 2012; Luo et al., 2019). For instance, MAT commonly decreases with increasing altitude, and coniferous forests and shrub are distributed at higher altitudes relative to broadleaf forests. Thus, the distribution patterns of trace metals in mountain soils are largely controlled by additive and/or interaction effects of multiple factors. In this study, we observed increasing $\mathrm{Cd}$ with altitude (Fig. 1). This was primarily attributed to atmospheric deposition regulated by regional and local climate because high-altitude areas feature low temperature, high wet precipitation, including snow, fog, and rain, and a low efficiency of SOM decomposition. The dominant regulation of soil $\mathrm{Cd}$ by atmospheric nitrogen deposition and climatic factors also supports the contribution of external inputs (Fig. 5). Meanwhile, relatively high concentrations of soil $\mathrm{Cd}$ and $\mathrm{Pb}$ were observed at medium altitudes (2000-3000 $\mathrm{m}$ for $\mathrm{Cd}$ and 1000-2000 $\mathrm{m}$ for $\mathrm{Pb}$, Fig. 1), which could be associated with vegetation effects. At these altitudes, vegetation composition and types are dominated by broadleaf-coniferous and/or coniferous trees according to our field investigation (Table S1). Broadleafconiferous and coniferous forests provide canopy filtering of clouds and fog (Evans et al., 2005; Gandois et al., 2010; Stankwitz et al., 2012), which can increase atmospheric metal deposition on the forest floor. Furthermore, a high return of litterfall exists in broadleaf-coniferous and coniferous forests, and the return effect could also increase metal accumulation through plant uptake or interception. Additionally, broadleafconiferous and coniferous trees have a greater capacity to acidify soils than deciduous trees (Andersen et al., 2004; Bing et al., 2018), which could accelerate metal leaching and loss from soils. More studies are required to understand the net effects of canopy interception and litter return versus soil acidification on the distribution of trace metals in mountain soils.
4.4 Implications of trace metal contamination and future perspectives

Inconsistent with traditional viewpoints, our study showed that the concentrations of trace metals in China's mountain soils were comparable to, or even higher than, those in agricultural and urban soils. In particular, the $\mathrm{Cd}$ concentrations in the $\mathrm{O}$ and $A$ horizons were four- and twofold higher, respectively, than the soil environmental quality standards in China (GB 15618-2018), and more than $60 \%$ of the soil samples exceeded this standard (Table 1). The contamination assessment also revealed a significant contamination of $\mathrm{Cd}$ in surface soils (Table 2). These results indicate that $\mathrm{Cd}$ is the priority metal pollutant in China's mountain soils. Therefore, $\mathrm{Cd}$ contamination needs to be highlighted because of its high mobility and toxicity (Bearup et al., 2014; Ning et al., 2019). Meanwhile, regional emissions combined with transboundary atmospheric transport are primary modes of inputting anthropogenic metals, such as $\mathrm{Cd}$ and $\mathrm{Pb}$ in the mountains, because we primarily selected mountains in national or provincial natural reserves where there is limited human disturbance. Although the government has implemented strict policies in recent years to protect the ecological environment, the soils in alpine regions have continuously been storing historical trace metals, especially since the Anthropocene. The legacy of metal contamination in mountain soils persists and becomes a potential threat to mountain health. Thus, it is necessary to stress the issue of $\mathrm{Cd}$ contamination in mountain soils.

The mountain critical zone is sensitive to human- and climate-induced rapid environmental changes (Le Roux et al., 2020). Mountain systems are experiencing strong climate and land-use changes (Hagedorn et al., 2010), which may alter the cycling of trace metals in the soil-plant system. However, the impacts of these changes on the fate of trace metals and their role in mountain health are largely unknown. Our results showed that trace metals had a close affinity to SOM, and soil $\mathrm{pH}$ regulated the mobilization of the metals in soils (Fig. 5). In a climate warming scenario, increased mineralization of SOM could release the metals bound with them and increase their mobilization. Meanwhile, climate warming will induce an upward shift of the vegetation zone in alpine regions (Sigdel et al., 2018). This will not only affect soil properties and the mobilization of trace metals, but it could also increase the atmospheric deposition of trace metals, because coniferous trees have a stronger interception capacity of atmospheric metals relative to shrub or broadleaf trees (Bing et al., 2018). Furthermore, although nitrogen deposition in China has not increased in recent years (Yu et al., 2019), we still need to determine the influence of soil acidification on trace metals, especially in the hotspots of acid deposition in south and southwest China, where the soil is highly contaminated with Cd (Fig. 1). Additionally, our study did not include the mountains in most areas of the Tibetan Plateau. The south of Asia, which has relatively high anthropogenic emissions, is 
a major source region of pollutants entering the Tibetan Plateau (Das et al., 2018; Kang et al., 2019). Whether the inputs of anthropogenic metals through long-range transboundary atmospheric transport affect the soil quality of the Tibetan Plateau needs to be determined in future.

\section{Conclusions}

In this study, we revealed that $\mathrm{Cd}$ is the priority metal requiring control in the soils of China's mountains, and its contamination levels reached moderate to heavy contamination. Additionally, we found a significant decrease in the concentrations of $\mathrm{Cd}$ and $\mathrm{Pb}$ with soil depth and higher concentrations in northwest, south, and southwest China. The increase in $\mathrm{Cd}$ with altitude and $\mathrm{Pb}$ isotopic tracing, combined with the data set on trace metal concentrations in moss and wet deposition, revealed that the contamination of $\mathrm{Cd}$ and $\mathrm{Pb}$ in surface soils was primarily from atmospheric deposition through long-range transboundary atmospheric transport. The anthropogenic sources of $\mathrm{Cd}$ and $\mathrm{Pb}$ in the soils were associated with China's resource exploitation and utilization, such as ore mining, nonferrous metal smelting, and coal and fuel combustion. Soil organic matters, $\mathrm{pH}$, and soil forming processes affected the fate of trace metals in the soils, while orographic effects, including climate effects, such as wet precipitation and cold condensation, vegetation composition, and canopy filtering, influenced the spatial and altitudinal distribution of the metals. In the context of climate warming, nitrogen and acid deposition, long-term monitoring of soil trace metal contamination and its role in ecosystem health in China's mountains is necessary to validate or improve biogeochemical models, which can be used to evaluate the responses of the mountain critical zone to future human- and climate-induced environmental changes.

\section{Acknowledgments}

All authors participated in the planning, execution, data analysis, and manuscript writing, and we have no conflicts of interest to this work. We declare no conflict of commercial or associative interest in this work. This work was supported by Youth Innovation Promotion Association of the Chinese Academy of Sciences (2017424), CAS "Light of West China" Program, and Special Talent Project of Sichuan Province. The authors also thank the anonymous reviewers for their helpful suggestions.

\section{References}

Abraham, P.W., 2002. Soils: their implications to human health. Science of the Total Environment 219, 1-32.

Andersen, M.K., Raulund-Rasmussen, K., Strobel, B.W., Hansen, H. C.B., 2004. The effects of tree species and site on the solubility of $\mathrm{Cd}, \mathrm{Cu}, \mathrm{Ni}, \mathrm{Pb}$ and $\mathrm{Zn}$ in soils. Water, Air, and Soil Pollution 154, 357-370.

Bacardit, M., Camarero, L., 2010. Modelling Pb, Zn and As transfer from terrestrial to aquatic ecosystems during the ice-free season in three Pyrenean catchments. Science of the Total Environment. 408, 5854-5861.

Bearup, L.A., Mikkelson, K.M., Wiley, J.F., Navarre-Sitchler, A.K., Maxwell, R.M., Sharp, J.O., McCray, J.E., 2014. Metal fate and partitioning in soils under bark beetle-killed trees. Science of the Total Environment 496, 348-357.

Bi, X.Y., Li, Z.G., Wang, S.X., Zhang, L., Xu, R., Liu, J.L., Yang, H.M., Guo, M.Z., 2017. Lead isotopic compositions of selected coals, $\mathrm{Pb} /$ $\mathrm{Zn}$ ores and fuels in China and the application for source tracing. Environmental Science \& Technology 51, 13502-13508

Bińczycki, T., Weber, J., Mielnik, L., Asensio, C., 2020. Lead isotope ratios in Podzol profiles as a tracer of pollution source in the subalpine zone of the Karkonosze National Park, Sudety Mts (south-western Poland). Catena 189, 104476.

Bing, H.J., Wu, Y.H., Li, J., Xiang, Z.X., Luo, X.S., Zhou, J., Sun, H., Zhang, G., 2019. Biomonitoring trace element contamination impacted by atmospheric deposition in China's remote mountains. Atmospheric Research 224, 30-41.

Bing, H.J., Wu, Y.H., Zhou, J., Li, R., Wang, J.P., 2016a. Historical trends of anthropogenic metals in eastern Tibetan Plateau as reconstructed from alpine lake sediments over the last century. Chemosphere 148, 211-219.

Bing, H.J., Wu, Y.H., Zhou, J., Li, R., Luo, J., Yu, D., 2016b. Vegetation and cold trapping modulating elevation-dependent distribution of trace metals in soils of a high mountain in eastern Tibetan Plateau. Scientific Reports 6, 24081.

Bing, H.J., Wu, Y.H., Zhou, J., Liang, J.H., Wang, J.P., Yang, Z.J., 2016c. Mobility and eco-risk of trace metals in soils at the Hailuogou Glacier foreland in eastern Tibetan Plateau. Environmental Science and Pollution Research 23, 5721-5732.

Bing, H.J., Wu, Y.H., Zhou, J., Ming, L.L., Sun, S.Q., Li, X.D., 2014. Atmospheric deposition of lead in remote high mountain of eastern Tibetan Plateau, China. Atmospheric Environment 99, 425- 435.

Bing, H.J., Zhou, J., Wu, Y.H., Luo, X.S., Xiang, Z.X., Sun, H.Y., Wang, J., Zhu, H., 2018. Barrier effects of remote high mountain on atmospheric metal transport in the eastern Tibetan Plateau. Science of the Total Environment 628, 687-696.

Bory, A.J.M., Abouchami, W., Galer, S.J.G., Svensson, A., Christensen, J.N., Biscaye, P.E., 2014. A Chinese imprint in insoluble pollutants recently deposited in central Greenland as indicated by lead isotopes. Environmental Science \& Technology 48, 14511457.

Chen, H., Teng, Y., Lu, S., Wang, Y., Wang, J., 2015. Contamination features and health risk of soil heavy metals in China. Science of the Total Environment 512-513, 143-153.

Chen, J., Liu, G., Kang, Y., Wu, B., Sun, R., Zhou, C., Wu, D., 2013. Atmospheric emissions of $\mathrm{F}, \mathrm{As}$, Se, $\mathrm{Hg}$, and $\mathrm{Sb}$ from coal-fired power and heat generation in China. Chemosphere 90, 19251932.

Chen, J.M., Tan, M.G., Li, Y.L., Zhang, Y.M., Lu, W.W., Tong, Y.P., Zhang, G., Li, Y., 2005. A lead isotope record of Shanghai atmospheric lead emissions in total suspended particles during the period of phasing out of leaded gasoline. Atmospheric Environment 39, 1245-1253.

Cheng, K., Wang, Y., Tian, H.Z., Gao, X., Zhang, Y.X., Wu, X.C., Zhu, 
C., Gao, J., 2015. Atmospheric emission characteristics and control policies of five precedent-controlled toxic heavy metals from anthropogenic sources in China. Environmental Science \& Technology 49, 1206-1214.

Das, R., Mohtar, A.T.B.M., Rakshit, D., Shome, D., Wang, X.F., 2018. Sources of atmospheric lead $(\mathrm{Pb})$ in and around an Indian megacity. Atmospheric Environment 193, 57-65.

Duan, C.J., Fang, L.C., Yang, C.L., Chen, W.B., Cui, Y.X., Li, S.Q., 2018. Reveal the response of enzyme activities to heavy metals through in situ zymography. Ecotoxicology and Environmental Safety $156,106-115$.

Elith, J., Leathwick, J.R., Hastie, T., 2008. A working guide to boosted regression trees. Journal of Animal Ecology 77, 802-813.

Evans, G., Norton, S., Fernandez, I., Kahl, J., Hanson, D., 2005. Changes in concentrations of major elements and trace metals in northeastern U.S.-Canadian sub-alpine forest floors. Water, Air, and Soil Pollution 163, 245-267.

Feng, J.L., Hu, Z.G., Cui, J.Y., Zhu, L.P., 2010. Distributions of lead isotopes with grain size in aeolian deposits. Terra Nova 22, 257 263

Gandois, L., Tipping, E., Dumat, C., Probst, A., 2010. Canopy influence on trace metal atmospheric inputs on forest ecosystems: speciation in throughfall. Atmospheric Environment 44, 824-833.

Hagedorn, F., Mulder, J., Jandl, R., 2010. Mountain soils under a changing climate and land-use. Biogeochemistry 97, 1-5.

Hansson, S.V., Claustres, A., Probst, A., De Vleeschouwer, F., Baron, S., Galop, D., Mazier, F., Le Roux, G., 2017. Atmospheric and terrigenous metal accumulation over 3000 years in a French mountain catchment: local vs distal influences. Anthropocene 19 45-54.

Harmens, H., Norris, D.A., Steinnes, E., Kubin, E., Piispanen, J., Alber, R., Aleksiayenak, Y., Blum, O., Coşkun, M., Dam, M., De Temmerman, L., Fernández, J.A., Frolova, M., Frontasyeva, M., González-Miqueo, L., Grodzińska, K., Jeran, Z., Korzekwa, S., Krmar, M., Kvietkus, K., Leblond, S., Liiv, S., Magnússon, S.H., Maňkovská, B., Pesch, R., Rühling, Å., Santamaria, J.M., Schröder, W., Spiric, Z., Suchara, I., Thöni, L., Urumov, V., Yurukova, L., Zechmeister, H.G., 2010. Mosses as biomonitors of atmospheric heavy metal deposition: spatial patterns and temporal trends in Europe. Environmental Pollution 158, 3144 3156.

Hou, Q.Y., Yang, Z.F., Yu, T., You, Y.H., Dou, L., Li, K., 2020. Impacts of parent material on distributions of potentially toxic elements in soils from Pearl River Delta in South China. Scientific Reports 10 , 17394.

Hou, S., Zheng, N., Tang, L., Ji, X., Li, Y., Hua, X., 2019. Pollution characteristics, sources, and health risk assessment of human exposure to $\mathrm{Cu}, \mathrm{Zn}, \mathrm{Cd}$ and $\mathrm{Pb}$ pollution in urban street dust across China between 2009 and 2018. Environment International 128 430-437.

Hovmand, M.F., Kemp, K., Kystol, J., Johnsen, I., Riis-Nielsen, T., Pacyna, J.M., 2008. Atmospheric heavy metal deposition accumulated in rural forest soils of southern Scandinavia. Environmental Pollution 155, 537-541.

Hu, B.F., Shao, S., Ni, H., Fu, Z.Y., Hu, L.S., Zhou, Y., Min, X., She, S., Chen, S., Huang, M., Zhou, L., Li, Y., Shi, Z., 2020. Current status, spatial features, health risks, and potential driving factors of soil heavy metal pollution in China at province level. Environmental Pollution. 266, 114961.

Huang, Y., Wang, L., Wang, W., Li, T., He, Z., Yang, X., 2019. Current status of agricultural soil pollution by heavy metals in China: a meta-analysis. Science of the Total Environment 651, 3034-3042.

Kang, S.C., Cong, Z.Y., Wang, X.P., Zhang, Q.G., Ji, Z.M., Zhang, Y.L., Xu, B.Q., 2019. The transboundary transport of air pollutants and their environmental impacts on Tibetan Plateau. Chinese Science Bulletin 64, 2876-2884.

Le Roux, G., Hansson, S.V., Claustres, A., 2016. Inorganic chemistry in the mountain critical zone: are the mountain water towers of contemporary society under threat by trace contaminants? Developments in Earth Surface Processes 21, 131-154.

Le Roux, G., Hansson, S.V., Claustres, A., Binet, S., De Vleeschouwer, F., Gandois, L., Mazier, F., Simonneau, A., Teisserenc, R., Allen, D., Rosset, T., Haver, M., Da Ros, L., Galop, D., Durantez, P., Probst, A., Sánchez-Pérez, J. M., Sauvage, S., Laffaille, P., Jean, S., Schmeller, D.S., Camarero, L., Marquer, L., Lofts, S., 2020. Trace Metal Legacy in Mountain Environments: A View from the Pyrenees Mountains. In: Dontsova, K., Balogh-Brunstad, Z., Le Roux, G., eds. Biogeochemical Cycles: Ecological Drivers and Environmental Impact, Geophysical Monograph 251, First Edition. John Wiley \& Sons, Inc, 191206.

Li, C., Sanchez, G.M., Wu, Z.F., Cheng, J., Zhang, S.Y., Wang, Q., Li, F., Sun, G., Meentemeyer, R.K., 2020. Spatiotemporal patterns and drivers of soil contamination with heavy metals during an intensive urbanization period (1989-2018) in southern China. Environmental Pollution 260, 114075.

Li, Q., Cheng, H.G., Zhou, T., Lin, C.Y., Guo, S., 2012. The estimated atmospheric lead emissions in China, 1990-2009. Atmospheric Environment 60, 1-8.

Li, R., Li, J., Cui, L., Wu, Y., Fu, H., Chen, J., Chen, M., 2017. Atmospheric emissions of $\mathrm{Cu}$ and $\mathrm{Zn}$ from coal combustion in China: spatiotemporal distribution, human health effects, and short-term prediction. Environmental Pollution 229, 724-734.

Li, Z.Y., Ma, Z.W., van der Kuijp, T.J., Yuan, Z.W., Huang, L., 2014. A review of soil heavy metal pollution from mines in China: pollution and health risk assessment. Science of the Total Environment 468, 843-853.

Liang, J., Zhang, L.X., 2009. Analysis on spatial distribution characteristics of urban energy consumption among capital cities in China. Resources Science 31, 2086-2092.

Liu, X., Tian, G., Jiang, D., Zhang, C., Kong, L., 2016. Cadmium (Cd) distribution and contamination in Chinese paddy soils on national scale. Environmental Science and Pollution Research 23, 1-12.

Luo, X.S., Bing, H.J., Luo, Z.X., Wang, Y.J., Jin, L., 2019. Impacts of atmospheric particulate matter pollution on environmental biogeochemistry of trace metals in soil-plant system: a review. Environmental Pollution 255, 113138

Luo, X.S., Yu, S., Zhu, Y., Li, X.D., 2012. Trace metal contamination in urban soils of China. Science of the Total Environment 421-422, 17-30.

MEP (The Ministry of Environmental Protection), 2014. The Ministry of Land and Resources Report on the National Soil Contamination 
Survey. http://www.gov.cn/foot/2014-04/17/content_2661768.htm

Muller, G., 1969. Index of geoaccumulation in sediments of the Rhine River. GeoJournal 2, 108-118.

Natalia, B., Olga, Y., Inna, T., Galina, M., 2019. Current state and dynamics of heavy metal soil pollution in Russian Federation - a review. Environmental. Pollution. 249, 200-207.

Ning, Y., Zhang, X., Li, B., Wang, Y., Guo, J., 2019. Distribution of Cd and $\mathrm{Cu}$ fractions in Chinese soils and their relationships with soil $\mathrm{pH}$ : a meta-analysis. Sustainability 11, 337-347.

Niu, L., Yang, F., Xu, C., Yang, H., Liu, W., 2013. Status of metal accumulation in farmland soils across China: from distribution to risk assessment. Environmental. Pollution. 176, 55-62.

Oliver, M.A., 1997. Soil and human health: a review. European Journal of Soil Science 48, 573-592.

Reimann, C., Fabian, K., Schilling, J., Roberts, D., Englmaier, P., 2015. A strong enrichment of potentially toxic elements (PTEs) in Nord-Trøndelag (central Norway) forest soil. Science of the Total Environment 536, 130-141.

Rieder, S.R., Tipping, E., Zimmermann, S., Graf-Pannatier, E., Waldner, P., Meili, M., Frey, B., 2014. Dynamic modelling of the long term behaviour of cadmium, lead and mercury in Swiss forest soils using CHUM-AM. Science of the Total Environment 468-469, 864-876.

Rockstrom, J., Steffen, W., Noone, K., Persson, A., Chapin, F.S. III, Lambin, E.F., Lenton, T.M., Scheffer, M., Folke, C., Schellnhuber, H.J., Nykvist, B., de Wit, C.A., Hughes, T., van der Leeuw, S., Rodhe, H., Sörlin, S., Snyder, P.K., Costanza, R., Svedin, U., Falkenmark, M., Karlberg, L., Corell, R.W., Fabry, V.J., Hansen, J., Walker, B., Liverman, D., Richardson, K., Crutzen, P., Foley, J.A., 2009. A safe operating space for humanity. Nature 461, 472-475.

Satarug, S., Garrett, S.H., Sens, M.A., Sens, D.A., 2010. Cadmium, environmental exposure, and health outcomes. Environmental Health Perspectives 118, 182-190.

Sigdel, S.R., Wang, Y.F., Camarero, J.J., Zhu, H.F., Liang, E.Y., Penuelas, J., 2018. Moisture-mediated responsiveness of treeline shifts to global warming in the Himalayas. Global Change Biology 5549-5559.

Stankwitz, C., Kaste, J.M., Friedland, A.J., 2012. Threshold increases in soil lead and mercury from tropospheric deposition across an elevational gradient. Environmental Science \& Technology 46, 8061-8068.

Steffen, W., Richardson, K., Rockström, J., Cornell, S.E., Fetzer, I., Bennett, E.M., Biggs, R., Carpenter, S.R., de Vries, W., de Wit, C. A., Folke, C., Gerten, D., Heinke, J., Mace, G.M., Persson, L.M., Ramanathan, V., Reyers, B., Sorlin, S., 2015. Planetary boundaries: guiding human development on a changing planet. Science 347, 1259855.

Steinnes, E., Friedland, A.J., 2006. Metal contamination of natural surface soils from long-range atmospheric transport: existing and missing knowledge. Environmental Reviews 14, 169-186.

Sun, L., Guo, D., Liu, K., Meng, H., Zheng, Y., Yuan, F., Zhu, G., 2019. Levels, sources, and spatial distribution of heavy metals in soils from a typical coal industrial city of Tangshan, China. Catena 175 , 101-109.

Taylor, S.R., McLennan, S.M., 1995. The geochemical evolution of the continental crust. Reviews of Geophysics 33, 241-265.
Teng, Y.G., Wu, J., Lu, S.J., Wang, Y.Y., Jiao, X.D., Song, L.T., 2014. Soil and soil environmental quality monitoring in China: a review. Environment International 69, 177-199.

Tian, H.X., Fang, L.C., Duan, C.J., Wang, Y.Q., Wu, H., 2018. Dominant factor affecting $\mathrm{Pb}$ speciation and the leaching risk among land-use types around $\mathrm{Pb}-\mathrm{Zn}$ mine. Geoderma 326, 123132.

Tian, H.Z., Liu, K., Zhou, J., Lu, L., Hao, J.M., Qiu, P., Gao, J., Zhu, C., Wang, K., Hua, S., 2014. Atmospheric emission inventory of hazardous trace elements from China's coal-fired power plants - temporal trends and spatial variation characteristics. Environmental Science \& Technology 48, 3575-3582.

Tóth, G., Hermann, T., Da Silva, M.R., Montanarella, L., 2016. Heavy metals in agricultural soils of the European Union with implications for food safety. Environment International 88, 299-309.

Wang, M.Q., Gao, Y.Y., 2007. Tracing source of geogas with lead isotopes: a case study in Jiaolongzhang $\mathrm{Pb}-\mathrm{Zn}$ deposit, Gansu Province. Geochimica 36, 391-399.

Wei, B., Yang, L., 2010. A review of heavy metal contaminations in urban soils, urban road dusts and agricultural soils from China. Microchemical Journal 94, 99-107.

Wu, Y.H., Bing, H.J., 2012. Ecogeochemistry in mountain region definition, progress and prospect. Geological Review 58, 106115.

Xiao, R., Wang, S., Li, R., Wang, J., Zhang, Z., 2017. Soil heavy metal contamination and health risks associated with artisanal gold mining in Tongguan, Shaanxi, China. Ecotoxicology and Environmental Safety 141, 17-24.

Xu, H.M., Sonke, J.E., Guinot, B., Fu, X.W., Sun, R.Y., Lanzanova, A., Candaudap, F., Shen, Z., Cao, J., 2017. Seasonal and annual variations in atmospheric $\mathrm{Hg}$ and $\mathrm{Pb}$ isotopes in Xi'an, China. Environmental Science \& Technology 51, 3759-3766.

Yang, Q.Q., Li, Z.Y., Lu, X.N., Duan, Q.N., Huang, L., Bi, J., 2018. A review of soil heavy metal pollution from industrial and agricultural regions in China: pollution and risk assessment. Science of the Total Environment 642, 690-700.

Yu, G., Jia, Y., He, N., Zhu, J., Chen, Z., Wang, Q., Piao, S., Liu, X., He, H., Guo, X., Wen, Z., Li, P., Ding, G., Goulding, K., 2019. Stabilization of atmospheric nitrogen deposition in China over the past decade. Nature Geoscience 12, 424-429.

Zechmeister, H.G., 1995. Correlation between altitude and heavy metal deposition in the Alps. Environmental Pollution 89, 73-80.

Zhang, X.X., Zha, T.G., Guo, X.P., Meng, G.X., Zhou, J.X., 2018. Spatial distribution of metal pollution of soils of Chinese provincial capital cities. Science of the Total Environment 643, 1502-1513.

Zhao, F.J., Ma, Y., Zhu, Y.G., Tang, Z., Mcgrath, S.P., 2015. Soil contamination in China: current status and mitigation strategies. Environmental Science \& Technology 49, 750-759.

Zhao, Y.J., Deng, Q.Y., Lin, Q., Zeng, C.Y., Zhong, C., 2020. Cadmium source identification in soils and high-risk regions predicted by geographical detector method. Environmental Pollution 263, 114338.

Zhu, J., Wang, Q., Yu, H., Li, M., He, N., 2016. Heavy metal deposition through rainfall in Chinese natural terrestrial ecosystems: evidences from national-scale network monitoring. Chemosphere $164,128-133$ 